Carbohydrate Research 389 (2014) 50-56

\title{
Preparation of new type of organocatalysts having a carbohydrate scaffold ${ }^{1 \S}$
}

Károly Ágoston ${ }^{2} *$ and Péter Fügedi

Institute of Organic Chemistry, Research Centre for Natural Sciences, Hungarian Academy of Sciences, Pusztaszeri út 59-67, H-1025 Budapest, Hungary

E-mail: agoston.karoly@ttk.mta.hu; fugedi.peter@ttk.mta.hu.

\section{ARTICLE INFO}

Received:

\section{ABSTRACT}

The synthesis of nine new, bifunctional organocatalysts having carbohydrate scaffolds has been accomplished. In these catalysts both of the catalytic amino and thiourea functions are directly attached to a carbohydrate core. The activities of the newly prepared catalysts were tested in a Michael addition.

Graphical abstract<smiles>[R]NC(=S)NC[C@H]1O[C@@H](OC)[C@H](OC)[C@H](OC)[C@H]1N[R]</smiles><smiles>COC1OC(CN2CCCCC2)[C@H](NC(=S)Nc2ccccc2)C(OC)[C@@H]1OC</smiles><smiles></smiles>

Keywords

Bifunctional organocatalysts, thiourea-amine type catalysts, carbohydrate scaffold, Michael addition

\footnotetext{
${ }_{\S}^{1}$ Presented at the 17th European Carbohydrate Symposium, Tel-Aviv, Israel, July 7-11, 2013, as poster July 7th P1

* Corresponding author. Tel.:+36 14381100 372; fax: +36 14381168 E-mail address agoston.karoly@ttk.mta.hu 


\section{Introduction}

In recent years, organocatalysis, the acceleration of various chemical reactions by catalytic amounts of organic molecules, emerged as one of the rapidly developing areas of organic chemistry. ${ }^{1}$ With the aid of organocatalysis a large number of chemical reactions could then be performed in stereoselective manner. Particularly great attention has been paid to the development of new, efficient catalysts. A special class of these catalysts is the so called bifunctional organocatalysts in which H-bond donor and Lewis base functionalities are combined in a single asymmetric molecular scaffold. Several different bifunctional catalysts have been designed, synthesized and tested. Most of these molecules have a combination of thiourea and amine groups as catalytic functionalities which are presented on a single chemical entity. The very first example of these catalysts has been described by Takemoto $^{2}$ in this molecule the catalytic centers are connected to a cyclohexane scaffold (compound $\mathbf{A}$, Figure 1). Later some different chiral scaffolds such as binaphtyl ${ }^{3}$ or cinchona alkaloid ${ }^{4}$ (compounds $\mathbf{B}$ and $\mathbf{C}$, Figure 1) were investigated and the catalysts based on these scaffolds showed promising results in asymmetric synthesis, particularly, in catalyzing Michael and aza-Henry reactions.

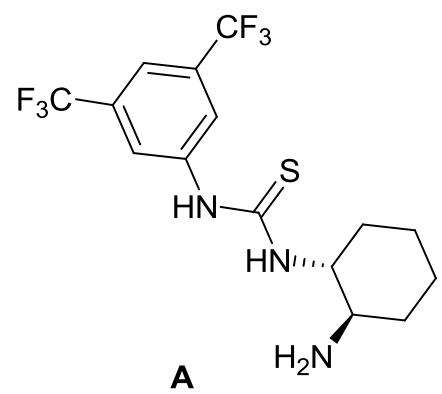

Takemoto's catalyst

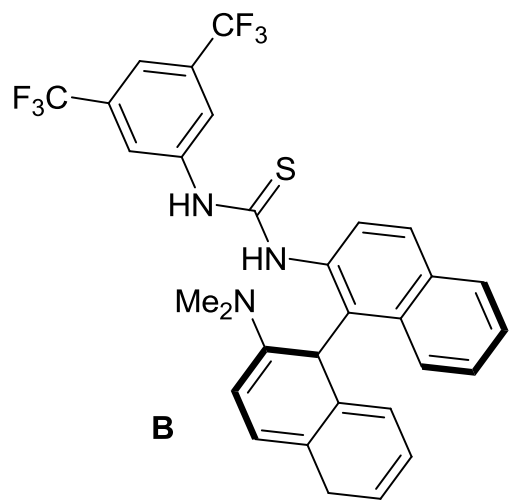

binaphtyl based catalyst<smiles>C=CC1C2CCN1C(=N[C@H](NC(=S)Nc1cc(C(F)(F)F)cc(C(F)(F)F)c1)c1ccnc3ccc(OC)cc13)C2</smiles>

cinchona based catalyst

Figure 1. Representative examples of bifunctional organocatalysts

To date only a limited number of scaffolds has been used to synthesize bifunctional organocatalysts. Monosaccharides as commercially available, inexpensive molecules of 
diverse chirality can be considered as obvious candidates for chiral scaffolds. Organocatalysts based on a D-glucosamine scaffold carrying urea and imine as catalytic functionalities were described by Kunz in 2007. ${ }^{5}$ Enantioselective Strecker and Mannich reactions were performed using these catalysts. ${ }^{5}$

Thiourea-amine type bifunctional organocatalysts containing a monosaccharide unit were prepared and their catalytic activities were investigated recently. ${ }^{6}$ In these cases, the carbohydrate moiety was located on the periphery of the catalyst molecule and not in-between the two catalytic centers (compounds $\mathbf{D}$ and E, Figure 2). To our knowledge there is only one example in the literature where a monosaccharide residue was used as a scaffold to connect thiourea and amine functionalities thereby defining the selectivity of the catalyzed reaction (compound F, Figure 2). ${ }^{7}$ In this study the use of urea derivatives, however, provided higher yields and selectivity than the corresponding thiourea derivative. ${ }^{7}$ Up to now, there are no examples of bifunctional thiourea-amine organocatalysts where the core scaffold is a monosaccharide unit and the use of the catalyst results in high yield and high enantioselectivity catalyzing a chemical reaction.

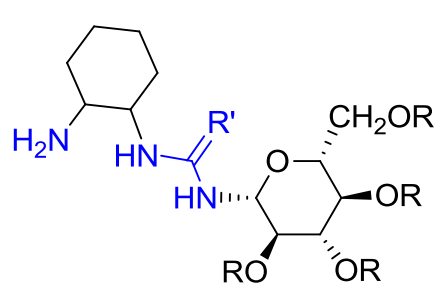

D

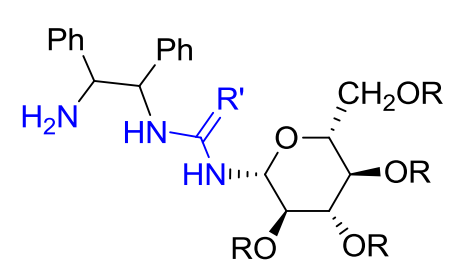

E

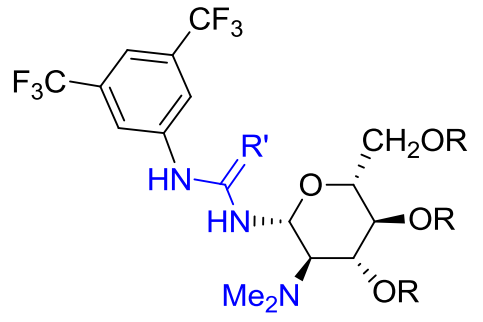

$\mathbf{F}$

Figure 2. Monosaccharide-containing bifunctional organocatalysts

We have initiated the preparation of new - bifunctional - thiourea-amine catalysts starting from D-glucose. In these molecules the two catalytic centers are connected with a carbohydrate residue. Using these catalysts the enantioselectivity of the catalyzed reaction will be influenced only by the carbohydrate moiety. The possible effect arising from carbohydrate chirality was taken into consideration in the design, by placing the catalytic groups at various positions of the carbohydrate scaffold. Thus the synthesis of molecules having the amino and thioureido groups in positions 4 and 6 ( $\mathbf{G}$ and $\mathbf{H}$, Figure 3), or in positions 2 and 3 (I, Figure 3), respectively, was planned. The catalytic groups are distanced by three carbon-carbon bonds in the first case, whereas they are separated by two C-C bonds in the latter. In the case of $\mathbf{G}$ and $\mathbf{H}$, the synthetic route was designed to afford both the 4- 
amino-6-thioureido $(\mathbf{G})$ and the 6-amino-4-thioureido $(\mathbf{H})$ derivatives from the same starting material.

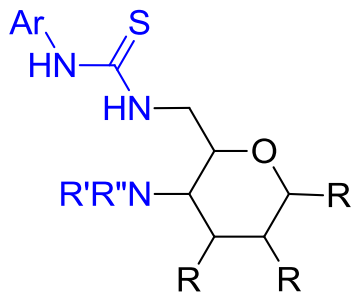

$\mathbf{G}$

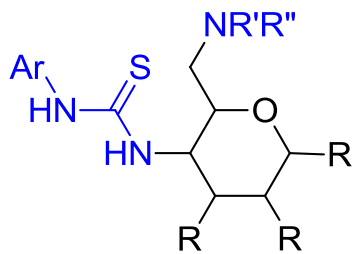

H<smiles>[R]CC1OC([R])C(N[R7])C(NC(=S)N[Al])C1[R]</smiles>

I

Figure 3. General structures of the targeted organocatalysts

\section{Results and discussion}

For the preparation of the targeted catalysts having the catalytic groups in the 4 and 6 positions, methyl 4-O-benzoyl-6-bromo-6-deoxy-2,3-di- $O$-methyl- $\alpha$-D-glucopyranoside ${ }^{8}$ (1, Scheme 1) was selected as starting material which is easily available from commercial methyl $\alpha$-D-glucopyranoside in a few steps in high yields.

The synthesis of the 4-amino-6-thioureido type compounds started with the preparation of the 6-azido derivative (2). Reaction of compound 1 with sodium azide in DMF at elevated temperature resulted in the formation of the 6-azido derivative $(\rightarrow \mathbf{2}$, Scheme 1$)$ in almost quantitative yield. The benzoate protecting group from compound $\mathbf{2}$ was removed with $\mathrm{NaOMe}$ in $\mathrm{MeOH}$ affording derivative 3 in high yield. 4-Amino derivatives were prepared by $\mathrm{S}_{N} 2$ replacement with primary amines via the 4-O-triflate in a one-pot manner. Treatment of $\mathbf{3}$ with triflic anhydride in $\mathrm{CH}_{2} \mathrm{Cl}_{2}$ in the presence of pyridine at $0 \mathrm{C}^{\mathrm{o}}$ afforded the crude 4-Otriflate, which was reacted directly with cyclohexylamine or benzylamine in the solvent mixture of $\mathrm{CH}_{2} \mathrm{Cl}_{2} / \mathrm{DMF}$ to yield the 4-cyclohexylamino (4) and 4-benzylamino (5) derivatives, respectively. The azido function of compound 4 was reduced to amine with propanedithiol in methanol ${ }^{9}$ and the 6-amino derivative was reacted with phenyl isothiocyanate $(\mathbf{4} \rightarrow \mathbf{6})$ or 3,5-bis(trifluoromethyl)phenyl isothiocyanate $(\mathbf{4} \rightarrow \mathbf{7})$ affording the bifunctional organocatalyst candidates. 


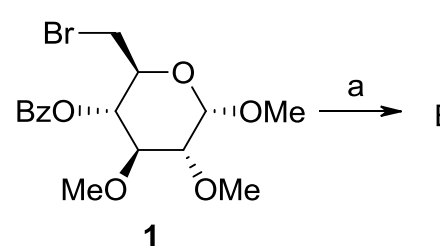

1

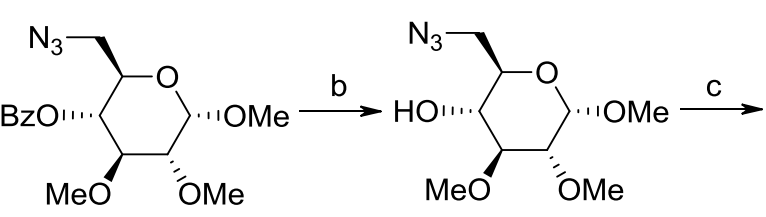

2
3

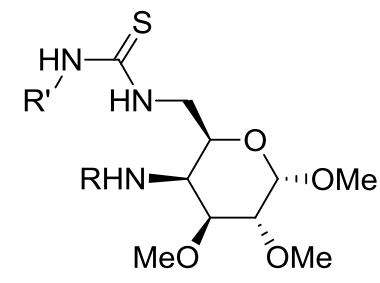

$6 \mathrm{R}=\mathrm{cHexyl}, \mathrm{R}^{\prime}=\mathrm{Ph}$

$7 \mathrm{R}=\mathrm{cHexyl}, \mathrm{R}^{\prime}=3,5-\mathrm{CF}_{3} \mathrm{Ph}$

$8 \mathrm{R}=$ Benzyl, $\mathrm{R}^{\prime}=\mathrm{Ph}$

$9 \mathrm{R}=$ Benzyl, $\mathrm{R}^{\prime}=3,5-\mathrm{CF}_{3} \mathrm{Ph}$

Scheme 1.

Conditions: $\quad$ a.) $\mathrm{NaN}_{3}$, DMF, $70{ }^{\circ} \mathrm{C}, 6$ h, $94 \%$; b.) $\mathrm{NaOMe}, \mathrm{MeOH}, \mathrm{rt} ., 1$ h, $80 \%$; c.) i: $\mathrm{Tf}_{2} \mathrm{O}$, pyridine, $\mathrm{CH}_{2} \mathrm{Cl}_{2}, 0{ }^{\circ} \mathrm{C}, 2 \mathrm{~h}$, ii: amine, DMF, $45^{\circ} \mathrm{C}, 10 \mathrm{~h}, 50-70 \%$; d.) i: propanedithiol, $\mathrm{MeOH}$, rt., $48 \mathrm{~h}\left(6\right.$ and 7), or $\mathrm{PPh}_{3}, \mathrm{H}_{2} \mathrm{O}, \mathrm{THF}, 80{ }^{\circ} \mathrm{C},(8$ and 9) ii: isothiocyanate, $\mathrm{MeOH}$, rt., 4 h, $30-50 \%$.

For the reduction of azido function of compound $\mathbf{5}$, the use of triphenylphosphine was found more advantageous, as reduction with propanedithiol resulted in impurities which were difficult to separate from the amino derivative. The amino derivative of compound $\mathbf{5}$ was reacted with phenyl isothiocyanate or 3,5-bis(trifluoromethyl)phenyl isothiocyanate affording derivatives $\mathbf{8}$ and $\mathbf{9}$, respectively.

For the preparation of the 6-amino-4-thioureido type target molecule nucleophilic substitution of the bromo function of compound $\mathbf{1}$ with piperidine was performed to afford $\mathbf{1 0}$ in high yield (Scheme 2). This reaction was significantly slower than the substitution of 1 with sodium azide. The removal of the benzoate protecting group from $\mathbf{1 0}$ by Zemplén's method required elevated temperature, but afforded compound $\mathbf{1 1}$ in good yield. The azido function was introduced at position 4 by $\mathrm{S}_{N} 2$ reaction via a triflate intermediate. Treatment of 11 with $\mathrm{Tf}_{2} \mathrm{O}$, as described for $\mathbf{4}$, followed by reaction of the crude with sodium azide in DMF afforded the 4-azido galacto epimer $(\mathbf{1 1} \rightarrow \mathbf{1 2})$. The stereochemistry was proven by the two small coupling constant of the H-4 in the ${ }^{1} \mathrm{H}-\mathrm{NMR}$ spectrum $\left(J_{3,4} 2.3 \mathrm{~Hz} J_{4,5}<1 \mathrm{~Hz}\right.$, ) while the presence on the azido group was indicated by the upfield shift of the $\mathrm{C}-4$ signal in the ${ }^{13} \mathrm{C}$ NMR spectrum. The transformation of the azido function into thiourea derivative was 
performed as in the case of compound 6. Treatment of $\mathbf{1 2}$ with propanedithiol resulted in the formation of the 4-amino intermediate which was reacted with phenyl isothiocyanate to form compound $\mathbf{1 3}$ as a catalyst candidate.

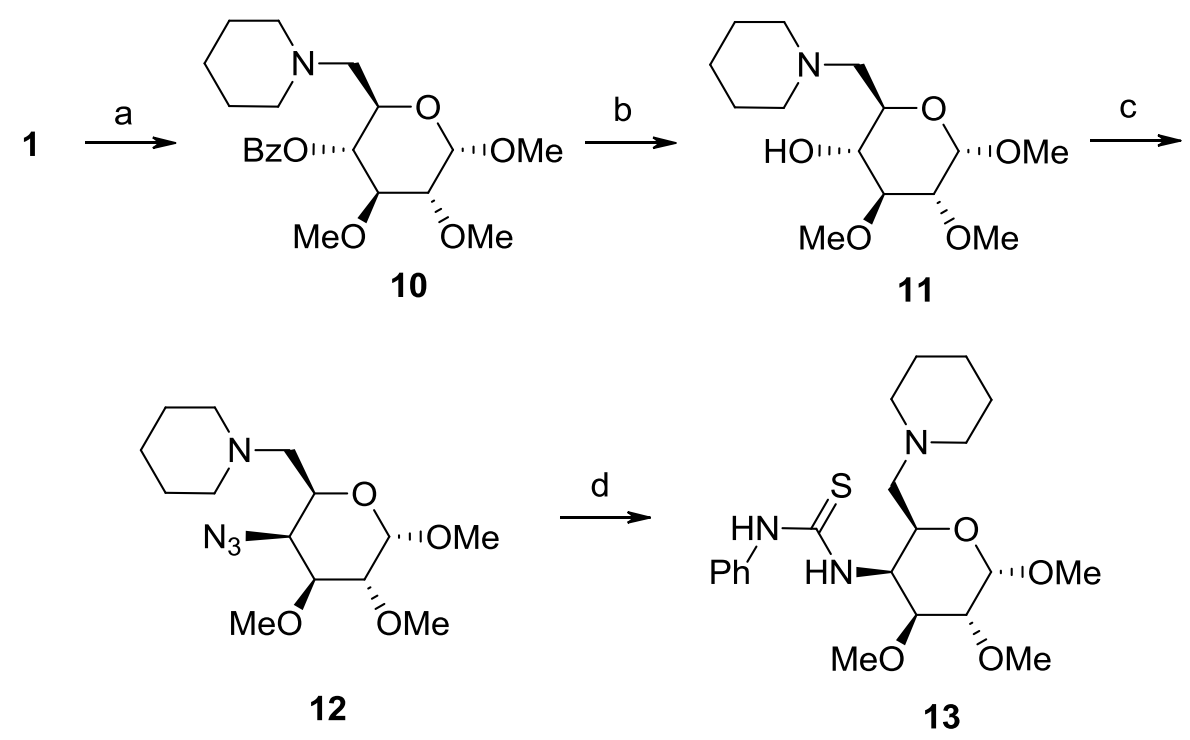

Scheme 2.

Conditions: a.) piperidine, $\mathrm{DMF}, 70{ }^{\circ} \mathrm{C}, 50$ h, $90 \%$; b.) $\mathrm{NaOMe}, \mathrm{MeOH}$, reflux, 2 h, 85\%; c.) i: $\mathrm{Tf}_{2} \mathrm{O}$, pyridine, $\mathrm{DCM}, 0{ }^{\circ} \mathrm{C}, 2 \mathrm{~h}$, ii: $\mathrm{NaN}_{3}, \mathrm{DMF}, 45^{\circ} \mathrm{C}, 72 \mathrm{~h}, 40 \%$; d.) i: propanedithiol, $\mathrm{MeOH}, \mathrm{rt}$, 48 h, ii: phenyl isothiocyanate, $\mathrm{MeOH}, \mathrm{rt} ., 8$ h, $69 \%$.

The preparation of the 2-amino-3-thioureido derivatives started from the allo-epoxide $14^{10}$ (Scheme 3 ) as starting material which is easily available from commercial methyl $\alpha$-Dglucopyranoside in a few steps in high yields. The epoxide was opened with piperidine or with morpholine according to a literature procedure ${ }^{11}$ affording the altro derivatives $\mathbf{1 5}$ and $\mathbf{1 6}$ in high yields. The preparation of the 3 -azido derivatives was accomplished by using Mistunobu conditions as only low yields were obtained in preliminary trials to introduce the azide by the displacement of the 3-O-triflate intermediate (data not shown). Compounds 15 and 16 were treated with diisopropyl azodicarboxylate and triphenylphosphine then with diphenylphosphoryl azide ${ }^{12}$ to form the 3 -azido derivatives $\mathbf{1 7}$ and $\mathbf{1 8}$, respectively. The azido functions of compounds 17 and 18 were reduced with triphenylphosphine, the resulting 3amino derivatives were subsequently treated with phenyl isothiocyanate or 3,5bis(trifluoromethyl)phenyl isothiocyanate affording the target compounds $(\mathbf{1 7} \rightarrow \mathbf{1 9}, \mathbf{1 7} \rightarrow \mathbf{2 0}$, $18 \rightarrow 21$ and $18 \rightarrow 22$ ). 


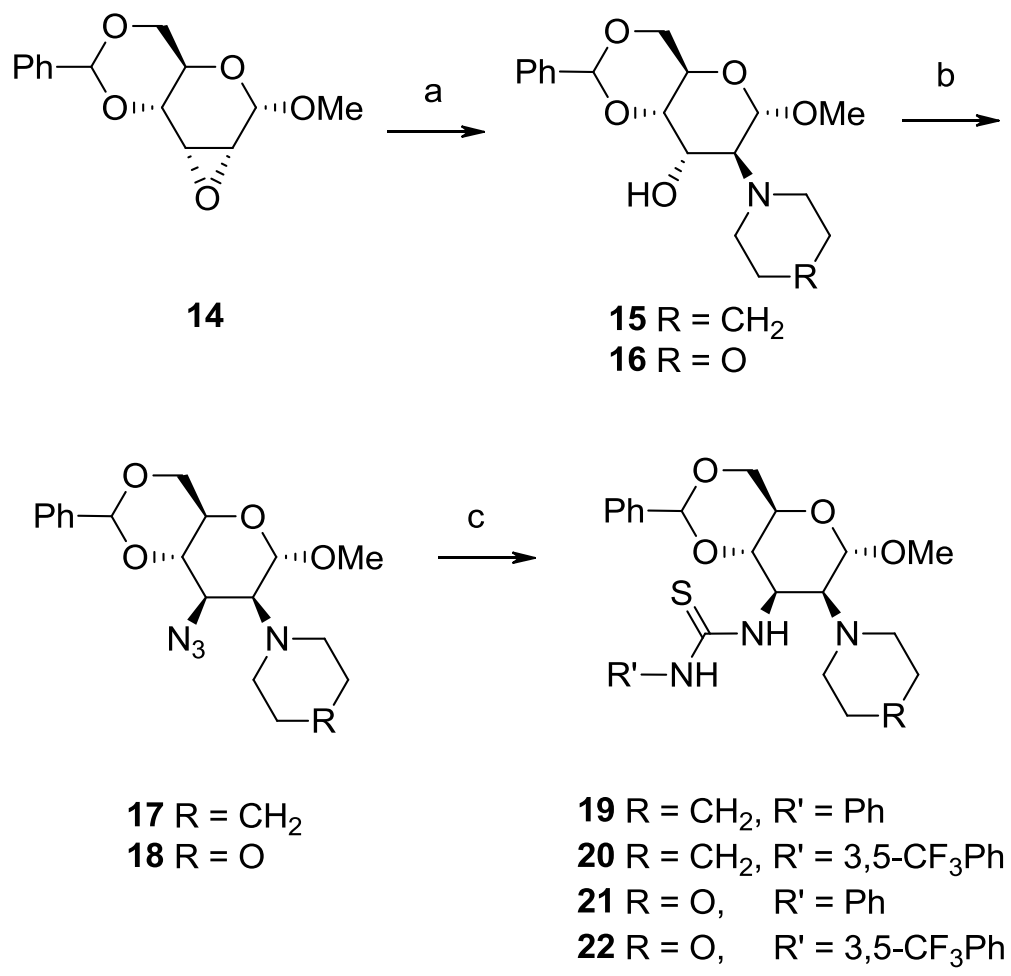

Scheme 3.

Conditions: a.) piperidine or morpholine, $\mathrm{LiClO}_{4}, \mathrm{MeCN}, 90{ }^{\circ} \mathrm{C}, 24 \mathrm{~h}, 80-90 \%$; b.) $\mathrm{i}: \mathrm{PPh}_{3}$, DIAD, THF, $0{ }^{\circ} \mathrm{C}$, ii: DPPA, THF, rt., 24 h, 60-80\%; c.) i: $\mathrm{PPh}_{3}$, THF, $\mathrm{H}_{2} \mathrm{O}, 80{ }^{\circ} \mathrm{C}$, ii: isothiocyanate, $\mathrm{MeOH}, \mathrm{rt}, 8 \mathrm{~h}, 60-80 \%$.

The catalytic activity of the prepared new, monosaccharide-based bifunctional organocatalysts was tested on the Michael addition of acetylacetone to $\beta$-nitrostyrene $(\rightarrow \mathbf{2 3}$, Scheme 4). This reaction is commonly used as test in evaluating newly developed organocatalysts. ${ }^{13}$ Based on preliminary experiments dichloromethane was selected as solvent for the reaction. The use of other solvents such as toluene, THF, MeCN, or diethyl ether resulted in much longer reaction times (data not shown). The stereochemistry of the products was determined by comparison of their optical rotation values (Table 1) with literature references ${ }^{13 c}$ together with the comparison of the chiral HPLC retention times with literature references. ${ }^{13 d, \mathrm{e}}$ The enantiomeric excess was determined by chiral HPLC. 

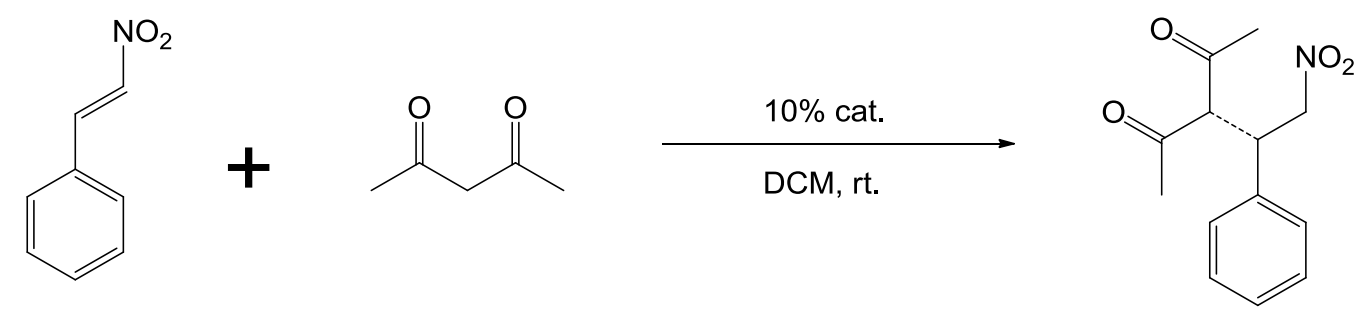

23

Scheme 4.

Conditions: $\beta$-nitrostyrene, 1.1 eq. acetylacetone, $10 \mathrm{~mol} \%$ catalyst, $\mathrm{CH}_{2} \mathrm{Cl}_{2}, \mathrm{rt}$., $24 \mathrm{~h}$.

The catalytic activity of the synthesized compounds is summarized in Table 1. Only those compounds which have secondary amine groups were able to promote the reaction to give good yields (Table 1, entries 1, 2, and 3). Tertiary amine-containing derivatives afforded very low yield or no reaction at all (entries 4,5 , and 6 ). The active catalysts favored the formation of the product having the $\mathrm{S}$ configuration, the enantioselectivity, however, was low. Further examination of the catalytic activity of prepared compounds on different reactions is in progress, and will be reported in due course.

Table 1. Summary of the catalytic activity of selected catalyst candidates.

\begin{tabular}{l|llll} 
Entry & catalyst & Yield $^{\mathbf{a}}$ & $\boldsymbol{e e \%}$ & {$[\boldsymbol{\alpha}]_{D}^{25}$ values } \\
\hline $\mathbf{1}$ & $\mathbf{6}$ & $70 \%$ & $18.7 \%$ & $13.9\left(c 0.5, \mathrm{CHCl}_{3}\right)$ \\
$\mathbf{2}$ & $\mathbf{7}$ & $78 \%$ & $14.1 \%$ & $8.0\left(c 0.5, \mathrm{CHCl}_{3}\right)$ \\
$\mathbf{3}$ & $\mathbf{9}$ & $50 \%$ & $12.9 \%$ & $7.8\left(c 0.65, \mathrm{CHCl}_{3}\right)$ \\
$\mathbf{5}$ & $\mathbf{1 9}$ & $<5 \%$ & n.d. & n.d. \\
$\mathbf{6}$ & $\mathbf{2 0}$ & none & - & - \\
& $\mathbf{2 1}$ & none & - & -
\end{tabular}

n.d.: not determined; ${ }^{\text {a }}$ Reaction times were $24 \mathrm{~h}$ in all cases. Without the use of catalyst no product formation was observed.

In conclusion, the synthesis of a new family of monosaccharide-based bifunctional organocatalysts has been achieved. Thiourea and amine functionalities were used as catalytic centers connected by a monosaccharide unit thereby replacing the commonly employed cyclohexane unit. The activities of the newly prepared catalysts were tested on a model 
reaction, where some of the compounds afforded high yields, although with low enantioselectivity.

\section{Experimental}

3.1. General. - Commercially available starting materials were used without further purification. Solvents were dried according to standard procedures. Melting points (uncorrected) were determined on a Griffin apparatus. Optical rotations were measured with a Jasco-Optical activity AA-10R polarimeter. NMR spectra were recorded on a Varian Gemini $2000\left(200 \mathrm{MHz}\right.$ for ${ }^{1} \mathrm{H}$ and $50 \mathrm{MHz}$ for ${ }^{13} \mathrm{C}$ ) and on a Varian Unity-Inova (300 MHz for ${ }^{1} \mathrm{H}$ and $75 \mathrm{MHz}$ for ${ }^{13} \mathrm{C}$ ) spectrometer in $\mathrm{CDCl}_{3}$ as solvent. All chemical shifts are quoted in ppm downfield from the characteristic signals $\left({ }^{1} \mathrm{H}: 0.00 \mathrm{ppm}(\mathrm{TMS}),{ }^{13} \mathrm{C}: 77.00 \mathrm{ppm}\left(\mathrm{CDCl}_{3}\right)\right)$. Kieselgel 60 (E. Merck, Darmstadt, Germany) was used for column chromatography and DCAlufolien Kieselgel $60 \mathrm{~F}_{256}$ plates were used for TLC. MS spectra were recorded on an Applied Biosystems 3200 QTRap spectrometer. Enantiomeric excesses were determined on a Waters 600 HPLC instrument. (Diacel Chiralpack AD column, hexane:i-propanol 80:20, flow rate: $1 \mathrm{~mL} / \mathrm{min}, \lambda=210 \mathrm{~nm}$ ).

\subsection{Methyl 6-azido-4- $O$-benzoyl-6-deoxy-2,3-di- $O$-methyl- $\alpha$-D-glucopyranoside (2)}

$\mathrm{NaN}_{3}$ (260 mg, $4.0 \mathrm{mmol}$ ) was added to a solution of $\mathbf{1}(780 \mathrm{mg}, 2.0 \mathrm{mmol})$ in dry DMF $(10 \mathrm{~mL})$ and the mixture was stirred for $6 \mathrm{~h}$ at $70{ }^{\circ} \mathrm{C}$. The mixture was allowed to cool to r.t. then it was diluted with EtOAc $(100 \mathrm{~mL})$ and washed with water $(3 \times 50 \mathrm{~mL})$. The organic layer was dried over $\mathrm{MgSO}_{4}$, filtered, concentrated and the product was obtained after column chromatography (toluene-acetone; 95:5) as a syrup (660 mg, 94\%). $[\alpha]_{D}^{25} 52.5(c$ 0.69, $\mathrm{CHCl}_{3}$ ); ${ }^{1} \mathrm{H}$ NMR: $\delta 8.06,7.60$, and 7.46 (m, $5 \mathrm{H}$, aromatic), 5.09 (dd, $1 \mathrm{H}, J_{3,4} 9.4 \mathrm{~Hz}$, $\left.J_{4,5} 9.9 \mathrm{~Hz}, \mathrm{H}-4\right), 4.93$ (d, $1 \mathrm{H}, J_{1,2} 3.5 \mathrm{~Hz}, \mathrm{H}-1$ ), 3.99 (ddd, $1 \mathrm{H}, J_{5,6} 5.4$ and 2.6 Hz, H-5), 3.74 (dd, $1 \mathrm{H}, J_{2,3} 9.2 \mathrm{~Hz}, \mathrm{H}-3$ ), 3.56, 3.52 and 3.48 (each s, each $3 \mathrm{H}, 3 \mathrm{OMe}$ ), 3.38 (m, $2 \mathrm{H}$, H-2 and H-6a), 3.27 (dd, $\left.1 \mathrm{H}, J_{\text {gem }} 13.3 \mathrm{~Hz}, \mathrm{H}-6 \mathrm{~b}\right) ;{ }^{13} \mathrm{C}$ NMR: $\delta 165.4$ (C=O), 133.4, 129.8, 129.3, and 128.5 (aromatic), 97.6 (C-1), 81.3 (C-2), 80.7 (C-3), 71.8 (C-4), 69.2 (C-5), 61.0, 59.3 and 55.5 (3 OMe), 51.3 (C-6); MS: Calcd. for: $\mathrm{C}_{16} \mathrm{H}_{21} \mathrm{~N}_{3} \mathrm{O}_{6} 351$, found: $352[\mathrm{M}+\mathrm{H}]^{+}, 374$ $[\mathrm{M}+\mathrm{Na}]^{+}, 725[2 \mathrm{M}+\mathrm{Na}]^{+}$. Anal. Calcd for $\mathrm{C}_{16} \mathrm{H}_{21} \mathrm{~N}_{3} \mathrm{O}_{6}$ : C, 54.69; H, 6.02. Found: C, 54.82; H, 6.05 . 
Carbohydrate Research 389 (2014) 50-56

\subsection{Methyl 6-azido-6-deoxy-2,3-di- $O$-methyl- $\alpha$-D-glucopyranoside (3)}

$\mathrm{NaOMe}(50 \mathrm{mg})$ was added to a solution of $2(660 \mathrm{mg}, 1.88 \mathrm{mmol})$ in dry MeOH (20 $\mathrm{mL})$. The mixture was stirred for $1 \mathrm{~h}$ at $\mathrm{rt}$. Then the mixture was neutralized with Amberlite IR-120 $\left(\mathrm{H}^{+}\right)$. The resin was filtered off and washed with $\mathrm{MeOH}$. The filtrate was concentrated and the product was isolated by column chromatography (toluene-acetone; 4:1). 3 (370 mg, 80\%) was obtained as a colorless syrup: $[\alpha]_{D}^{25} 117.0\left(c 0.58, \mathrm{CHCl}_{3}\right) ;{ }^{1} \mathrm{H}$ NMR: $\delta 4.81$ (d, 1 $\left.\mathrm{H}, J_{1,2} 3.5 \mathrm{~Hz}, \mathrm{H}-1\right), 3.70$ (m, $1 \mathrm{H}, \mathrm{H}-5$ ), 3.60, 3.46 and 3.41 (each s, each $3 \mathrm{H}, 3 \mathrm{OMe}$ ), 3.50 (dd, $1 \mathrm{H}, J_{\text {gem }} 13.2 \mathrm{~Hz}, \mathrm{H}-6 \mathrm{a}$ ), 3.44-3.30 (m, $3 \mathrm{H}, \mathrm{H}-3, \mathrm{H}-4$ and H-6b) 3.20 (dd, $1 \mathrm{H}, J_{2,3} 9.2$ Hz, H-2) 2.18 (bs, $1 \mathrm{H}, 4-\mathrm{OH}$ ); ${ }^{13} \mathrm{C}$ NMR: $\delta 97.3$ (C-1), 82.6 (C-3), 81.7 (C-2), 70.4 and 70.3 (C-4 and C-5), 61.1, 58.4 and 55.3 (3 OMe), 51.4 (C-6); MS: Calcd. for: $\mathrm{C}_{9} \mathrm{H}_{17} \mathrm{~N}_{3} \mathrm{O}_{5} 247$, found: $270[\mathrm{M}+\mathrm{Na}]^{+}, 517[2 \mathrm{M}+\mathrm{Na}]^{+}$. Anal. Calcd for $\mathrm{C}_{9} \mathrm{H}_{17} \mathrm{~N}_{3} \mathrm{O}_{5}: \mathrm{C}, 43.72 ; \mathrm{H}, 6.93$. Found: C, 43.67; H, 6.95.

\subsection{Methyl 6-azido-4-cyclohexylamino-4,6-dideoxy-2,3-di- $O$-methyl- $\alpha$-D- galactopyranoside (4)}

A solution of $\mathrm{Tf}_{2} \mathrm{O}(1.63 \mathrm{~mL}, 9.7 \mathrm{mmol})$ in $\mathrm{CH}_{2} \mathrm{Cl}_{2}(5 \mathrm{~mL})$ was added to a solution of $3(1.61 \mathrm{~g}, 6.7 \mathrm{mmol})$ in a mixture of pyridine $(3.2 \mathrm{~mL})$ and $\mathrm{CH}_{2} \mathrm{Cl}_{2}(20 \mathrm{~mL})$ at $0{ }^{\circ} \mathrm{C}$, then the mixture was stirred for $2 \mathrm{~h}$ at $0{ }^{\circ} \mathrm{C}$. TLC (hexane-EtOAc; $1: 1$ ) showed the formation of a new apolar derivative. Cyclohexylamine $(6 \mathrm{~mL})$ in DMF $(20 \mathrm{~mL})$ was added to the mixture and stirring was continued for $10 \mathrm{~h}$ at $45^{\circ} \mathrm{C}$. Then the mixture was concentrated and the residue was purified by column chromatography (hexane-EtOAc; $1: 1)$ to provide $4(1.1 \mathrm{~g}, 51 \%)$ as a pale yellow syrup. $[\alpha]_{D}^{25} 136.4\left(c 0.64, \mathrm{CHCl}_{3}\right) ;{ }^{1} \mathrm{H}$ NMR: $\delta 4.86\left(\mathrm{~d}, 1 \mathrm{H}, J_{1,2} 3.5 \mathrm{~Hz}, \mathrm{H}-1\right)$, 3.78 (m, $1 \mathrm{H}, \mathrm{H}-5$ ), 3.60 (dd, $\left.1 \mathrm{H}, J_{\text {gem }} 12.2 \mathrm{~Hz}, \mathrm{H}-6 \mathrm{a}\right), 3.51$ (dd, $1 \mathrm{H}, J_{2,3} 9.5 \mathrm{~Hz}, J_{3,4} 3.6 \mathrm{~Hz}$, H-3), 3.44, 3.42, and 3.41 (each s, each 3 H, 3 OMe), 3.35 (dd, $1 \mathrm{H}, \mathrm{H}-2$ ), 3.16 (dd, $1 \mathrm{H}, \mathrm{H}-$ 6b) 3.08 (dd, $\left.1 \mathrm{H}, J_{4,5} \sim 1 \mathrm{~Hz}, \mathrm{H}-4\right), 2.25$ (m, $1 \mathrm{H}$, cyclohexyl CH), 1.80-1.50 and 1.20-0.70 (m, $10 \mathrm{H}$, cyclohexyl $\mathrm{CH}_{2}$ ); ${ }^{13} \mathrm{C}$ NMR: $\delta 97.3$ (C-1), 79.1 (C-3), $77.1(\mathrm{C}-2), 70.3(\mathrm{C}-5), 58.6$, 57.8 and 55.2 (3 OMe), 56.8 (cyclohexyl $\mathrm{CH}$ ) 53.7 (C-4), 52.2 (C-6), 34.5, 33.6, 25.8, 25.2, 25.0 (5 cyclohexyl $\mathrm{CH}_{2}$ ); MS: Calcd. for: $\mathrm{C}_{15} \mathrm{H}_{28} \mathrm{~N}_{4} \mathrm{O}_{4} 328$, found: 329 [M+H] $]^{+}$; HRMS: $[\mathrm{M}+\mathrm{H}]^{+}$calcd. for 329.2189, found: 329.2191. 
Carbohydrate Research 389 (2014) 50-56

\subsection{Methyl 6-azido-4-benzylamino-4,6-dideoxy-2,3-di- $O$-methyl- $\alpha$-D- galactopyranoside (5)}

Compound 3 (1.61 g, $6.7 \mathrm{mmol}$ ) was converted into the 4-O-triflate intermediate as described for compound 4. A solution of benzylamine $(6 \mathrm{~mL})$ in DMF $(20 \mathrm{~mL})$ was added to the triflate intermediate and the mixture was stirred for $10 \mathrm{~h}$ at $45^{\circ} \mathrm{C}$. Then the mixture was concentrated and the residue was purified by column chromatography (hexane-EtOAc; $1: 1$ ) to give $5(1.67 \mathrm{~g}, 76 \%)$ as a pale yellow syrup: $[\alpha]_{D}^{25} 117.2\left(\mathrm{c} 0.8, \mathrm{CHCl}_{3}\right) ;{ }^{1} \mathrm{H}$ NMR: $\delta 7.40$ 7.20 (m, $5 \mathrm{H}$, aromatic), 4.95 (d, $\left.1 \mathrm{H}, J_{1,2} 3.7 \mathrm{~Hz}, \mathrm{H}-1\right), 3.85$ (m, $3 \mathrm{H}, \mathrm{H}-5$ and benzyl $\mathrm{CH}_{2}$ ), 3.70 and 3.22 (each dd, $2 \mathrm{H}, J_{5,6} 8.8$ and $4.2 \mathrm{~Hz}, J_{\text {gem }} 12.5 \mathrm{~Hz}, \mathrm{H}-6 \mathrm{a}$ ), 3.60 (dd, $1 \mathrm{H}, J_{2,3} 9.9$ $\mathrm{Hz}, J_{3,4} 4.2 \mathrm{~Hz}, \mathrm{H}-3$ ), 3.48, 3.44 and 3.28 (each s, each 3 H, $3 \mathrm{OMe}$ ), 3.43 (dd, $\left.1 \mathrm{H}, \mathrm{H}-2\right), 3.10$ (dd, $\left.1 \mathrm{H}, J_{4,5} 1.3 \mathrm{~Hz}, \mathrm{H}-4\right)$; ${ }^{13} \mathrm{C}$ NMR: $\delta 140.1,128.3$, and 127.1 (aromatic), 97.5 (C-1), 79.4 (C-3), 77.1 (C-2), 70.2 (C-5), 58.6, 57.4 and 55.2 (3 OMe), 55.4 (C-4), 54.4 (benzyl $\mathrm{CH}_{2}$ ), 52.3 (C-6); MS: Calcd. for: $\mathrm{C}_{16} \mathrm{H}_{24} \mathrm{~N}_{4} \mathrm{O}_{4} 336$, found: 337 [M+H] $]^{+}$. Anal. Calcd for $\mathrm{C}_{16} \mathrm{H}_{24} \mathrm{~N}_{4} \mathrm{O}_{4}$ : C, 57.13; H, 7.19. Found: C, 57.07; H, 7.18.

\subsection{Methyl 4-cyclohexylamino-4,6-dideoxy-2,3-di- $O$-methyl-6-( $N$ '-phenyl)thioureido- $\alpha$-D-galactopyranoside (6)}

Propanedithiol $(2.0 \mathrm{~mL})$ was added to a solution of $4(0.8 \mathrm{~g}, 2.4 \mathrm{mmol})$ in $\mathrm{MeOH}(20$ $\mathrm{mL}$ ) at $\mathrm{rt}$ and the mixture was stirred for $48 \mathrm{~h}$ at $\mathrm{rt}$. When TLC (hexane-EtOAc, 1:1) showed the formation of the 6-amino derivative the mixture was filtered, the filtrate was evaporated and the residue was purified by column chromatography $\left(\mathrm{CH}_{2} \mathrm{Cl}_{2}-\mathrm{MeOH}-\right.$ water; 8:5:1) to afford the amino derivative $(0.65 \mathrm{~g})$. Phenyl isothiocyanate $(400 \mu \mathrm{L})$ was added to a solution of the amino derivative $(650 \mathrm{mg})$ in $\mathrm{MeOH}(10 \mathrm{~mL})$ at $\mathrm{rt}$. The mixture was stirred for $4 \mathrm{~h}$ then concentrated. After column chromatography $\left(\mathrm{CH}_{2} \mathrm{Cl}_{2}-\mathrm{MeOH}-\right.$ water; 8:5:1) of the residue a white solid was obtained, which was recrystallized from EtOAc to yield 6 (450 mg, $42 \%$, over two steps): m.p 160-162 ${ }^{\circ} \mathrm{C} ;[\alpha]_{D}^{25} 84.7$ (c 0.54, $\left.\mathrm{CHCl}_{3}\right) ;{ }^{1} \mathrm{H} \mathrm{NMR}: \delta 8.36$ (bs, $\left.1 \mathrm{H}, \mathrm{NH}\right)$, 7.42-7.20 (m, 5 H, aromatic), 4.80 (d, 1 H, J1,2 3.7 Hz, H-1), 4.32 (bs, 1 H, H-6a), 3.86 (m, 1 H, H-5), 3.57 (dd, 1 H, $J_{2,3} 10.2$ Hz, $J_{3,4} 4.7$ Hz, H-3), 3.48 (m, $1 \mathrm{H}, \mathrm{H}-6 \mathrm{~b}$ ), 3.46, 3.42, and 3.20 (each s, each 3 H, 3 OMe), 3.30 (dd, 1 H, H-2), 3.14 (dd, 1 H, H-4), 2.28 (m, 1 H, cyclohexyl $\mathrm{CH}), 1.80-1.50$ and $1.20-0.70\left(\mathrm{~m}, 10 \mathrm{H}\right.$, cyclohexyl $\left.\mathrm{CH}_{2}\right) ;{ }^{13} \mathrm{C}$ NMR: $\delta 180.0$ $(\mathrm{C}=\mathrm{S}), 136.3,129.8,126.8$, and 125.0 (aromatic), 97.4 (C-1), 79.0 (C-3), 77.1 (C-2), 68.0 (C- 
5), 58.5, 58.0 and 54.9 (3 OMe), 56.9 (cyclohexyl $C H$ ) 54.5 (C-4), 47.2 (C-6), 34.0, 33.3, 25.7, 25.0, 24.9 (5 cyclohexyl $\mathrm{CH}_{2}$ ); MS: Calcd. for: $\mathrm{C}_{22} \mathrm{H}_{35} \mathrm{~N}_{3} \mathrm{O}_{4} \mathrm{~S} 437$, found: $438[\mathrm{M}+\mathrm{H}]^{+}$. Anal. Calcd for $\mathrm{C}_{22} \mathrm{H}_{35} \mathrm{~N}_{3} \mathrm{O}_{4} \mathrm{~S}$ : C, 60.38; H, 8.06. Found: C, 60.42; H, 8.04.

\subsection{Methyl 4-cyclohexylamino-4,6-dideoxy-2,3-di- $O$-methyl-6-( $N$ '-3,5- bis(trifluoromethyl)phenyl)thioureido- $\alpha$-D-galactopyranoside (7)}

Compound 4 (0.8 g, $2.4 \mathrm{mmol})$ was converted into the 6-amino derivative as described for compound 6. 3,5-Bis(trifluoromethyl)phenyl isothiocyanate $(400 \mu \mathrm{L})$ was added to a solution of the 6-amino derivative $(0.65 \mathrm{~g})$ in $\mathrm{MeOH}(10 \mathrm{~mL})$ at $\mathrm{rt}$. The mixture was stirred for $4 \mathrm{~h}$ then concentrated and the product was isolated after column chromatography (hexaneEtOAc; 1:2) as a white solid. The solid was recrystallized from EtOAc to yield 7 (530 mg, 35 $\%$, over two steps): m.p. $189-191^{\circ} \mathrm{C} ;[\alpha]_{D}^{25} 39.7$ (c 0.51, $\left.\mathrm{CHCl}_{3}\right) ;{ }^{1} \mathrm{H}$ NMR: $\delta 10.18$ (bs, $1 \mathrm{H}$, 6-NH), 8.95 (bs, $1 \mathrm{H}, \mathrm{NH}), 7.84$ (s, $2 \mathrm{H}$, aromatic) 7.68 (s, $1 \mathrm{H}$, aromatic), 4.95 (d, $1 \mathrm{H}, J_{1,2}$ $3.5 \mathrm{~Hz}, \mathrm{H}-1$ ), 4.40 (m, $1 \mathrm{H}, \mathrm{H}-6 \mathrm{a}), 3.96$ (m, $1 \mathrm{H}, \mathrm{H}-5), 3.65$ (dd, $1 \mathrm{H}, J_{2,3} 10.4 \mathrm{~Hz}, J_{3,4} 4.7 \mathrm{~Hz}$, $\mathrm{H}-3$ ), 3.55, 3.46 and 3.44 (each s, each $3 \mathrm{H}, 3 \mathrm{OMe}$ ), 3.45 (m, $1 \mathrm{H}, \mathrm{H}-6 \mathrm{~b}), 3.28$ (dd, $1 \mathrm{H}, \mathrm{H}-2$ ), 3.22 (dd, $1 \mathrm{H}, \mathrm{H}-4), 2.37$ (m, $1 \mathrm{H}$, cyclohexyl CH), 1.60-1.44 and 1.20-0.50 (m, $10 \mathrm{H}$, cyclohexyl $\left.\mathrm{CH}_{2}\right) ;{ }^{13} \mathrm{C}$ NMR: $\delta 178.8(\mathrm{C}=\mathrm{S}), 139.5$ (aromatic quaterner), $132.8\left(\mathrm{q}, 2 \mathrm{C},{ }^{2} J_{\mathrm{C}, \mathrm{F}} 33\right.$ Hz, C-3" and C-5”), 122.9 (q, 2 C, ${ }^{1} J_{\mathrm{C}, \mathrm{F}} 271 \mathrm{~Hz}, 2 \mathrm{CF}_{3}$ ), 122.8 (m, 2 C, C-2" and C-6"), 118.4 (m, 1 C, C-4”), 97.7 (C-1), 79.4 (C-3), 77.2 (C-2), 65.5 (C-5), 58.7, 58.6 and 55.5 (3 OMe), 57.0 (cyclohexyl $C \mathrm{H}$ ) 54.3 (C-4), 49.3 (C-6), 33.2, 32.8, 25.5, 24.8, 24.6 (5 cyclohexyl $C_{2}$ ); MS: Calcd. for: $\mathrm{C}_{24} \mathrm{H}_{33} \mathrm{~F}_{6} \mathrm{~N}_{3} \mathrm{O}_{4} \mathrm{~S} 573$, found: $574[\mathrm{M}+\mathrm{H}]^{+}$. Anal. Calcd for $\mathrm{C}_{24} \mathrm{H}_{33} \mathrm{~F}_{6} \mathrm{~N}_{3} \mathrm{O}_{4} \mathrm{~S}$ : C, 50.25; H, 5.80. Found: C, 50.31; H, 5.82.

\subsection{Methyl 4-benzylamino-4,6-dideoxy-2,3-di- $O$-methyl-6-( $N$ '-phenyl)thioureido- $\alpha$-D- galactopyranoside $(8)$}

Triphenylphosphine $(1.2 \mathrm{~g}, 4.6 \mathrm{mmol})$ was added to a solution of 5 (1.0 g, $3.0 \mathrm{mmol})$ in THF $(20 \mathrm{~mL})$ at $\mathrm{rt}$ and the mixture was stirred for $2 \mathrm{~h}$ at $80^{\circ} \mathrm{C}$. When TLC (hexaneEtOAc; $1: 1)$ showed the absence of the starting material water $(2 \mathrm{~mL})$ was added to the mixture and the stirring was continued for $4 \mathrm{~h}$ at $80{ }^{\circ} \mathrm{C}$. The mixture was concentrated, the residue was purified by column chromatography $\left(\mathrm{CH}_{2} \mathrm{Cl}_{2}-\mathrm{MeOH}\right.$-water 8:5:1) affording the 6-amino derivative $(0.7 \mathrm{~g})$. Phenyl isothiocyanate $(225 \mu \mathrm{L})$ was added to a solution the 6- 
amino-derivative $(485 \mathrm{mg})$ in $\mathrm{MeOH}(10 \mathrm{~mL})$ at $\mathrm{rt}$. The mixture was stirred for $24 \mathrm{~h}$ then concentrated and the product was obtained after column chromatography $\left(\mathrm{CH}_{2} \mathrm{Cl}_{2}-\mathrm{MeOH}-\right.$ water 8:5:1) as a white solid. The solid was recrystallized from $\mathrm{CH}_{2} \mathrm{Cl}_{2} /$ hexane to yield $\mathbf{8}$ (281 $\mathrm{mg}, 31 \%$, over two steps) as white crystals: mp $100-102{ }^{\circ} \mathrm{C} ;[\alpha]_{D}^{25} 116.9\left(c 0.65, \mathrm{CHCl}_{3}\right) ;{ }^{1} \mathrm{H}$ NMR: $\delta 8.18(\mathrm{~s}, 1 \mathrm{H}, \mathrm{NHPh}), 7.40-7.18(\mathrm{~m}, 10 \mathrm{H}$, aromatic), $6.92(\mathrm{~d}, 1 \mathrm{H}, 6-\mathrm{NH}), 4.78$ (d, 1

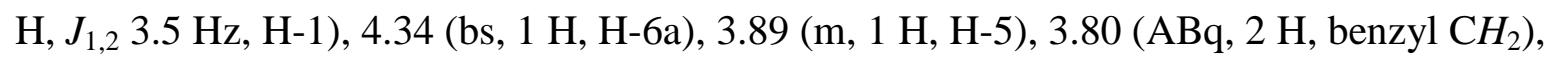
3.68 (m, $1 \mathrm{H}, \mathrm{H}-6 \mathrm{~b}), 3.59$ (dd, $1 \mathrm{H}, J_{2,3} 10.3 \mathrm{~Hz}, J_{3,4} 3.6 \mathrm{~Hz}, \mathrm{H}-3$ ), 3.44, 3.25 and 3.17 (each s, each $3 \mathrm{H}, 3 \mathrm{OMe}$ ), 3.35 (dd, $1 \mathrm{H}, \mathrm{H}-2), 3.13$ (dd, $1 \mathrm{H}, \mathrm{H}-4), 1.66$ (bs, $1 \mathrm{H}, 4-\mathrm{NH}) ;{ }^{13} \mathrm{C}$ NMR: $\delta$ $180.4(\mathrm{C}=\mathrm{S}), 139.7,136.1,129.9,128.4,127.1$ and 125.2 (aromatic), 97.6 (C-1), 79.0 (C-3), 77.0 (C-2), 68.6 (C-5), 58.7, 57.4 and 55.0 (3 OMe), 56.2 (C-4), 54.9 (benzyl $\mathrm{CH}_{2}$ ), 47.1 (C6); MS: Calcd. for: $\mathrm{C}_{23} \mathrm{H}_{31} \mathrm{~N}_{3} \mathrm{O}_{4} \mathrm{~S} 445$, found: $446[\mathrm{M}+\mathrm{H}]^{+}$. Anal. Calcd for $\mathrm{C}_{23} \mathrm{H}_{31} \mathrm{~N}_{3} \mathrm{O}_{4} \mathrm{~S}: \mathrm{C}$, 62.00; H, 7.01. Found: C, 62.07; H, 7.02.

\subsection{Methyl 4-benzylamino-4,6-dideoxy-2,3-di- $O$-methyl-6-( $N^{\prime}-3,5-$}

\section{bis(trifluoromethyl)phenyl)thioureido- $\alpha$-D-galactopyranoside (9)}

Compound 5 (1.0 g $3.0 \mathrm{mmol})$ was converted into the 6-amino derivative as described for 8. 3,5-Bis(trifluoromethyl)phenyl isothiocyanate $(350 \mu \mathrm{L})$ was added to a solution of the 6-amino derivative $(497 \mathrm{mg})$ in $\mathrm{MeOH}(10 \mathrm{~mL})$ at $\mathrm{rt}$. The mixture was stirred for $10 \mathrm{~min}$, during this time a light brown precipitate was formed. The solid was filtered and was purified by recrystallization from EtOAc/hexane to afford 9 (868 $\mathrm{mg}, 70 \%$, over two steps) as white crystals: mp $180-182{ }^{\circ} \mathrm{C} ;[\alpha]_{D}^{25} 69.9\left(c 0.89, \mathrm{CHCl}_{3}\right) ;{ }^{1} \mathrm{H}$ NMR: $\delta 9.28$ (bs, $\left.1 \mathrm{H}, \mathrm{NH}\right), 8.66$ (bs, $1 \mathrm{H}, \mathrm{NH}), 7.50-7.40\left(\mathrm{~m}, 8 \mathrm{H}\right.$, aromatic) 4.90 (d, $\left.1 \mathrm{H}, J_{1,2} 3.5 \mathrm{~Hz}, \mathrm{H}-1\right), 4.40$ (m, $1 \mathrm{H}, \mathrm{H}-$ 6a), 4.00 (m, $1 \mathrm{H}, \mathrm{H}-5$ ), 3.84 and 3.55 (each m, $2 \mathrm{H}$, benzyl $\mathrm{CH}_{2}$ ), 3.70 (dd, $1 \mathrm{H}, J_{2,3} 10.2 \mathrm{~Hz}$, $J_{3,4} 4.7 \mathrm{~Hz}, \mathrm{H}-3$ ), 3.65 (m, $1 \mathrm{H}, \mathrm{H}-6 \mathrm{~b}$ ), 3.51, 3.41 and 3.40 (each s, each $3 \mathrm{H}, 3 \mathrm{OMe}$ ), 3.34 (dd, 1 H, H-2), 3.22 (dd, 1 H, H-4), 2.00 (bs, 1 H, 4-NH); ${ }^{13} \mathrm{C}$ NMR: $\delta 179.6(\mathrm{C}=\mathrm{S}), 139.5$ (aromatic quaterner), 132.8 (C-3" and C-5”), 129.2, 128.8, 128.1, and 127.6 (aromatic), 123.2 (q, 2 C, ${ }^{1} J_{\mathrm{C}, \mathrm{F}} 271 \mathrm{~Hz}, 2 \mathrm{CF}_{3}$ ), 121.4 (m, 2 C, C-2" and C-6"), 114.9 (m, 1 C, C-4”), 98.0 (C-1), 79.1 (C-3), 77.9 (C-2), 66.1 (C-5), 59.4 (C-4), 59.0, 58.4 and 55.8 (3 OMe), 55.7 (benzyl $\mathrm{CH}_{2}$ ), 49.1 (C-6); MS: Calcd. for: $\mathrm{C}_{25} \mathrm{H}_{29} \mathrm{~F}_{6} \mathrm{~N}_{3} \mathrm{O}_{4} \mathrm{~S} 581$, found: 582 [M+H] $]^{+}$. Anal. Calcd for $\mathrm{C}_{25} \mathrm{H}_{29} \mathrm{~F}_{6} \mathrm{~N}_{3} \mathrm{O}_{4} \mathrm{~S}: \mathrm{C}, 51.63 ; \mathrm{H}, 5.03$. Found: $\mathrm{C}, 51.51 ; \mathrm{H}, 5.00$. 


\subsection{Methyl 4-O-benzoyl-6-deoxy-2,3-di- $O$-methyl-6-piperidino- $\alpha$-D-glucopyranoside} (10)

Piperidine $(720 \mu \mathrm{L}, 7.3 \mathrm{mmol})$ was added to a solution of $\mathbf{1}(1.12 \mathrm{~g}, 2.88 \mathrm{mmol})$ in dry DMF $(5 \mathrm{~mL})$ and the mixture was stirred for $50 \mathrm{~h}$ at $70{ }^{\circ} \mathrm{C}$. Then the mixture was allowed to cool to r.t., it was diluted with toluene $(100 \mathrm{~mL})$ and washed with water $(2 \times 30 \mathrm{~mL})$, the organic layer was dried over $\mathrm{MgSO}_{4}$, filtered, and concentrated. Column chromatography (toluene-acetone; 3:1) of the residue afforded $\mathbf{1 0}(1.01 \mathrm{~g}, 90 \%)$ as a syrup: $[\alpha]_{D}^{25} 80.2(c 0.63$, $\mathrm{CHCl}_{3}$ ); ${ }^{1} \mathrm{H}$ NMR: $\delta$ 8.05, 7.55 and $7.42\left(\mathrm{~m}, 5 \mathrm{H}\right.$, aromatic), 5.00 (dd, $1 \mathrm{H}, J_{3,4} 9.4 \mathrm{~Hz}, J_{4,5} 9.9$ Hz, H-4), 4.86 (d, 1 H, J1,2 3.5 Hz, H-1), 4.03 (m, 1 H, H-5), 3.66 (dd, 1 H, J2,3 9.4 Hz, H-3), 3.51, 3.46 and 3.43 (each s, each $3 \mathrm{H}, 3 \mathrm{OMe}$ ), 3.31 (dd, $1 \mathrm{H}, \mathrm{H}-2), 2.50$ and 2.36 (each dd, 2 $\mathrm{H}, J_{\text {gem }} 13.4 \mathrm{~Hz}, \mathrm{H}-6$ ), 2.33, 1.46 and 1.30 (each m, $10 \mathrm{H}, 5$ piperidine $\mathrm{CH}_{2}$ ); ${ }^{13} \mathrm{C}$ NMR: $\delta$ $165.5(\mathrm{C}=\mathrm{O}), 133.1,129.7$ and 128.3 (aromatic), $97.5(\mathrm{C}-1), 81.4(\mathrm{C}-2), 81.0(\mathrm{C}-3), 73.2$ (C4), 66.9 (C-5), 60.8, 59.2 and 55.5 (3 OMe), 60.1 (C-6), 55.1, 25.7 and 24.1 (5 piperidine $\mathrm{CH}_{2}$ ); MS: Calcd. for: $\mathrm{C}_{21} \mathrm{H}_{31} \mathrm{NO}_{6} 393$, found: $394[\mathrm{M}+\mathrm{H}]^{+}$. Anal. Calcd for $\mathrm{C}_{21} \mathrm{H}_{31} \mathrm{NO}_{6}: \mathrm{C}$, 64.10; H, 7.94. Found: C, 64.03; H, 7.92.

\subsection{Methyl 6-deoxy-2,3-di- $O$-methyl-6-piperidino- $\alpha$-D-glucopyranoside (11)}

$\mathrm{NaOMe}(50 \mathrm{mg})$ was added to a solution of $\mathbf{1 0}(1.0 \mathrm{~g}, 2.54 \mathrm{mmol})$ in dry $\mathrm{MeOH}$ (20 $\mathrm{mL}$ ) at r.t., then the mixture was stirred for $2 \mathrm{~h}$ at reflux. The mixture was concentrated and the residue was purified by column chromatography $\left(\mathrm{CH}_{2} \mathrm{Cl}_{2}-\mathrm{MeOH} ; 95: 5 \rightarrow 8: 2\right)$ to give $\mathbf{1 1}$ (618 mg, 85\%) as a colorless syrup: $[\alpha]_{D}^{25} 73.4\left(c 0.63, \mathrm{CHCl}_{3}\right) ;{ }^{1} \mathrm{H}$ NMR: $\delta 4.68\left(\mathrm{~d}, 1 \mathrm{H}, J_{1,2}\right.$ $3.5 \mathrm{~Hz}, \mathrm{H}-1), 3.60$ (m, $1 \mathrm{H}, \mathrm{H}-5), 3.56,3.42$ and 3.32 (each s, each $3 \mathrm{H}, 3 \mathrm{OMe}), 3.40$ (m, $2 \mathrm{H}$, H-3 and H-4), 3.10 (dd, $1 \mathrm{H}, \mathrm{H}-2), 2.60$ (m, $\left.2 \mathrm{H}, J_{\text {gem }} 12.3 \mathrm{~Hz}, \mathrm{H}-6\right), 2.55,2.30,1.50$ and 1.33 (each m, $10 \mathrm{H}, 5$ piperidine $\mathrm{CH}_{2}$ ); ${ }^{13} \mathrm{C}$ NMR: $\delta 97.5$ (C-1), 82.0 (C-3), 81.0 (C-2), $71.1(\mathrm{C}-4)$, 64.4 (C-5), 63.1 (C-6), 60.8, 58.6 and 55.0 (3 OMe), 55.4, 25.7 and 23.3 (5 piperidine $\mathrm{CH}_{2}$ ); MS: Calcd. for: $\mathrm{C}_{14} \mathrm{H}_{27} \mathrm{NO}_{5} 289$, found: $290[\mathrm{M}+\mathrm{H}]^{+}, 312[\mathrm{M}+\mathrm{Na}]^{+}$. Anal. Calcd for $\mathrm{C}_{14} \mathrm{H}_{27} \mathrm{NO}_{5}$ : C, 58.11; H, 9.40. Found: C, 58.10; H, 9.37.

\subsection{Methyl 4-azido-4,6-dideoxy-2,3-di- $O$-methyl-6-piperidino- $\alpha$-D-galactopyranoside}


A solution of $\mathrm{Tf}_{2} \mathrm{O}(1.89 \mathrm{~mL}, 11.3 \mathrm{mmol})$ in $\mathrm{CH}_{2} \mathrm{Cl}_{2}(5 \mathrm{~mL})$ was added to a solution of $11(2.16 \mathrm{~g} 7.5 \mathrm{mmol})$ in a mixture of pyridine $(3.6 \mathrm{~mL})$ and $\mathrm{CH}_{2} \mathrm{Cl}_{2}(50 \mathrm{~mL})$ at $0{ }^{\circ} \mathrm{C}$ and the mixture was stirred for $2 \mathrm{~h}$ at $0{ }^{\circ} \mathrm{C}$. Sodium azide $(980 \mathrm{mg})$ in DMF $(50 \mathrm{~mL})$ was added to the mixture and stirring was continued for $72 \mathrm{~h}$ at $45^{\circ} \mathrm{C}$. Then the mixture was concentrated and the residue was purified by column chromatography $\left(\mathrm{CH}_{2} \mathrm{Cl}_{2}-\mathrm{MeOH}, 95: 5\right)$ to yield 12 (700 mg, 30\%) as a pale yellow syrup: $[\alpha]_{D}^{25} 104.8\left(c 0.65, \mathrm{CHCl}_{3}\right) ;{ }^{1} \mathrm{H} \mathrm{NMR} \delta: 4.72\left(\mathrm{~d}, 1 \mathrm{H}, J_{1,2}\right.$ $3.4 \mathrm{~Hz}, \mathrm{H}-1$ ), 4.10 (dd, $1 \mathrm{H}, J_{3,4} 2.3 \mathrm{~Hz} J_{4,5}<1 \mathrm{~Hz}, \mathrm{H}-4$ ), 3.90 (m, $1 \mathrm{H}, \mathrm{H}-5$ ), 3.69 (dd, $1 \mathrm{H}, J_{2,3}$ $9.8 \mathrm{~Hz}, \mathrm{H}-3$ ), 3.58, 3.56 and 3.40 (each s, each $3 \mathrm{H}, 3 \mathrm{OMe}$ ), 3.50 (m, $1 \mathrm{H}, \mathrm{H}-2), 2.50$ (m, $6 \mathrm{H}$, H-6 and 2 piperidine $\mathrm{CH}_{2}$ ), 1.60 and 1.40 (each m, $6 \mathrm{H}, 3$ piperidine $\mathrm{CH}_{2}$ ); ${ }^{13} \mathrm{C}$ NMR: $\delta 98.2$ (C-1), 79.8 (C-3), 78.1 (C-2), 66.3 (C-5), 61.7 (C-4), 59.7 (C-6), 59.4, 58.4 and 55.8 (3 OMe), 55.6, 26.2 and 24.4 (5 piperidine $C \mathrm{H}_{2}$ ); MS: Calcd. for: $\mathrm{C}_{14} \mathrm{H}_{26} \mathrm{~N}_{4} \mathrm{O}_{4} 314$, found: $315[\mathrm{M}+\mathrm{H}]^{+}$, $332\left[\mathrm{M}+\mathrm{NH}_{4}\right]^{+}$. Anal. Calcd for $\mathrm{C}_{14} \mathrm{H}_{26} \mathrm{~N}_{4} \mathrm{O}_{4}: \mathrm{C}, 53.49 ; \mathrm{H}, 8.34$. Found: C, 53.42; H, 8.32.

\subsection{Methyl 4,6-dideoxy-2,3-di- $O$-methyl-6-piperidino-4-( $N$ '-phenyl)thioureido- $\alpha$-D- galactopyranoside (13)}

Propanedithiol $(200 \mu \mathrm{L})$ was added to a solution of $12(300 \mathrm{mg}, 0.95 \mathrm{mmol})$ in $\mathrm{MeOH}$ $(5 \mathrm{~mL})$ at $\mathrm{rt}$ and the mixture was stirred for $72 \mathrm{~h}$ at $50{ }^{\circ} \mathrm{C}$. When TLC $\left(\mathrm{CH}_{2} \mathrm{Cl}_{2}-\mathrm{MeOH}, 95: 5\right)$ showed the formation of the 4-amino derivative, the mixture was filtered and the filtrate was concentrated. The residue was dissolved in $\mathrm{MeOH}(10 \mathrm{~mL})$ and phenyl isothiocyanate (200 $\mu \mathrm{L}$ ) was added to the solution. The mixture was stirred for $8 \mathrm{~h}$ at $\mathrm{rt}$, then it was concentrated and the residue was purified by column chromatography $\left(\mathrm{CH}_{2} \mathrm{Cl}_{2}-\mathrm{MeOH} ; 95: 5\right)$ to afford 13 (280 mg, $69 \%$ over two steps) as a syrup: $[\alpha]_{D}^{25} 122.5\left(c\right.$ 0.59, $\left.\mathrm{CHCl}_{3}\right) ;{ }^{1} \mathrm{H} \mathrm{NMR}: \delta 8.78$ (bd, $1 \mathrm{H}, \mathrm{NH}), 7.45-7.20$ (m, $5 \mathrm{H}$, aromatic), 6.51 (bs, $1 \mathrm{H}, \mathrm{NH}), 5.30$ (bd, $1 \mathrm{H}, \mathrm{H}-4), 4.80$ (d, 1 H, $J_{1,2} 3.0 \mathrm{~Hz}, \mathrm{H}-1$ ), 4.10 (m, $1 \mathrm{H}, \mathrm{H}-5$ ), 3.67 (dd, 1 H, $J_{2,3} 10.3 \mathrm{~Hz}, J_{3,4} 4.4$ Hz, H-3), 3.53, 3.50 and 3.38 (each s, each 3 H, 3 OMe), 3.11 (m, 1 H, H-2), 2.66 (dd, 1 H, H-6a), 2.46 (m, 5 $\mathrm{H}, \mathrm{H}-6 \mathrm{~b}$ and 2 piperidine $\mathrm{CH}_{2}$ ), 1.58 and 1.42 (each $\mathrm{m}, 6 \mathrm{H}, 3$ piperidine $\mathrm{CH}_{2}$ ); ${ }^{13} \mathrm{C}$ NMR: $\delta$ $181.5(\mathrm{C}=\mathrm{S}), 136.7,129.6,126.5$ and 126.6 (aromatic), 97.6 (C-1), 78.2 (C-3), 77.6 (C-2), 65.9 (C-5), 59.1 (C-6), 58.9, 58.1 and 55.6 (3 OMe), 54.5 (C-4), 54.9, 25.3 and 23.7 (5 piperidine $\mathrm{CH}_{2}$ ); MS: Calcd. for: $\mathrm{C}_{21} \mathrm{H}_{33} \mathrm{~N}_{3} \mathrm{O}_{4} \mathrm{~S} 423$, found: $424[\mathrm{M}+\mathrm{H}]^{+}$. Anal. Calcd for $\mathrm{C}_{21} \mathrm{H}_{33} \mathrm{~N}_{3} \mathrm{O}_{4} \mathrm{~S}$ : C, 59.55; H, 7.85. Found: C, 59.58; H, 7.89.

\subsection{Methyl 4,6-O-benzylidene-2-deoxy-2-piperidino- $\alpha$-D-altropyranoside (15)}


Piperidine $(6.73 \mathrm{~mL})$ and $\mathrm{LiClO}_{4}(3.62 \mathrm{~g})$ were added to a solution of 14 (4.5 g, 17.0 $\mathrm{mmol})$ in $\mathrm{MeCN}(50 \mathrm{~mL})$ at $\mathrm{rt}$ and the mixture was stirred for $24 \mathrm{~h}$ at $90{ }^{\circ} \mathrm{C}$. Then the mixture was concentrated, the residue was redissolved in EtOAc $(300 \mathrm{~mL})$ and washed with water (3 $\times 150 \mathrm{~mL}$ ), the organic layer was dried, filtered and concentrated. After column chromatography $\left(\mathrm{CH}_{2} \mathrm{Cl}_{2}-\mathrm{MeOH} ; 95: 5\right) 15$ (5.7 g, $\left.95 \%\right)$ was obtained as white crystals:. mp $83-85{ }^{\circ} \mathrm{C}$ (hexane/EtOAc), lit $^{11} \mathrm{mp} 117-118{ }^{\circ} \mathrm{C} ;[\alpha]_{D}^{25} 74.3$ (c $\left.0.64, \mathrm{CHCl}_{3}\right) ; \operatorname{lit}^{11}[\alpha]_{D}^{25} 90.8(c$ 1.3, $\mathrm{CH}_{2} \mathrm{Cl}_{2}$ ); ${ }^{1} \mathrm{H}$ NMR: $\delta 7.54$ - 7.32 (m, $5 \mathrm{H}$, aromatic), 5.64 (s, $\left.1 \mathrm{H},-\mathrm{CHPh}\right), 4.80(\mathrm{~s}, 1 \mathrm{H}$, H-1), 4.32 (dd, 1 H, J Jem 10.1 Hz, H-6a), 4.13 (m, 2 H, H-3 and H-5), 3.90 (dd, 1 H, J3,4 2.9 Hz, J J,5 9.8 Hz, H-4), 3.80 (dd, 1 H, H-6b), 3.40 (s, 3 H, OMe), 3.18 (d, 1 H, J3, OH 4.7 Hz, 3$\mathrm{OH}), 2.84$ (d, $\left.1 \mathrm{H}, J_{2,3} 2.1 \mathrm{~Hz}, \mathrm{H}-2\right), 2.70$ and 2.55 (each m, each $2 \mathrm{H}, 2-\mathrm{CH}_{2^{-}}$), 1.60 and 1.45 (m, $6 \mathrm{H},-\mathrm{CH}_{2^{-}}$); ${ }^{13} \mathrm{C}$ NMR: $\delta$ 137.4, 129.1, 128.2 and 126.2 (aromatic), 102.1 (-CHPh), 101.2 (C-1), 77.8 (C-4), 69.4 (C-6), 67.8 (C-2), 65.6 and 57.7 (C-3 and C-5), 55.3 (OMe), 51.8, 26.5 and $24.2\left(5-\mathrm{CH}_{2}\right)$; MS: Calcd. for: $\mathrm{C}_{19} \mathrm{H}_{27} \mathrm{NO}_{5} 349$, found: $350[\mathrm{M}+\mathrm{H}]^{+}$.

\section{3,15 Methyl 4,6-O-benzylidene-2-deoxy-2-morpholino- $\alpha$-D-altropyranoside (16)}

Morpholine (5.9 mL) and $\mathrm{LiClO}_{4}(3.62 \mathrm{~g})$ were added to a solution of $\mathbf{1 4}$ (4.5 g, 17.0 $\mathrm{mmol})$ in $\mathrm{MeCN}(50 \mathrm{~mL})$ at $\mathrm{rt}$ and the mixture was stirred for $24 \mathrm{~h}$ at $90{ }^{\circ} \mathrm{C}$. Then the mixture was concentrated and the residue was taken up in EtOAc $(300 \mathrm{~mL})$ and washed with water (3 $\times 150 \mathrm{~mL}$ ), the organic layer was dried, filtered and concentrated. Purification of the residue by column chromatography $\left(\mathrm{CH}_{2} \mathrm{Cl}_{2}-\mathrm{MeOH} ; 95: 5\right)$ afforded $16(5.0 \mathrm{~g}, 84 \%)$ as white crystals:. mp $117-119^{\circ} \mathrm{C}$ (hexane), lit $^{11} \mathrm{mp} 118-119^{\circ} \mathrm{C} ;[\alpha]_{D}^{25} 73.2\left(c 0.71, \mathrm{CHCl}_{3}\right) ;$ lit $^{11}$ $[\alpha]_{D}^{25} 71.7$ (c 1.2, $\mathrm{CH}_{2} \mathrm{Cl}_{2}$ ); ${ }^{1} \mathrm{H}$ NMR: $\delta 7.54$ - 7.32 (m, $5 \mathrm{H}$, aromatic), 5.64 (s, $\left.1 \mathrm{H},-\mathrm{CHPh}\right)$, 4.83 (s, $1 \mathrm{H}, \mathrm{H}-1$ ), 4.32 (dd, 1 H, $\left.J_{\text {gem }} 10.1 \mathrm{~Hz}, \mathrm{H}-6 \mathrm{a}\right), 4.16$ (m, 2 H, H-3 and H-5), 3.92 (dd, 1 H, $\left.J_{3,4} 3.1 \mathrm{~Hz}, J_{4,5} 9.8 \mathrm{~Hz}, \mathrm{H}-4\right), 3.79$ (dd, $1 \mathrm{H}, \mathrm{H}-6 \mathrm{~b}$ ), 3.70 (t, $4 \mathrm{H},-\mathrm{CH}_{2} \mathrm{OCH}_{2^{-}}$), 3.42 (s, $3 \mathrm{H}$, OMe), 3.17 (d, $\left.1 \mathrm{H}, J_{3, \mathrm{OH}} 6.6 \mathrm{~Hz}, 3-\mathrm{OH}\right), 2.79$ (d, $1 \mathrm{H}, J_{2,3} 1.9 \mathrm{~Hz}, \mathrm{H}-2$ ), 2.70 and 2.60 (each

m, each $\left.2 \mathrm{H}, 2-\mathrm{CH}_{2^{-}}\right) ;{ }^{13} \mathrm{C}$ NMR: $\delta$ 137.2, 129.0, 128.2 and 126.2 (aromatic), $102.2(-\mathrm{CHPh})$, 100.0 (C-1), 77.4 (C-4), $69.2(\mathrm{C}-6), 67.2\left(-\mathrm{CH}_{2} \mathrm{OCH}_{2}-\right), 67.0$ (C-2), 65.9 and 57.8 (C-3 and C5), $55.4(\mathrm{OMe}), 51.1\left(2 \times-\mathrm{CH}_{2}\right)$; MS: Calcd. for: $\mathrm{C}_{18} \mathrm{H}_{25} \mathrm{NO}_{6} 351$, found: $352[\mathrm{M}+\mathrm{H}]^{+}$.

\subsection{Methyl 3-azido-4,6- $O$-benzylidene-2,3-dideoxy-2-piperidino- $\alpha$-D- mannopyranoside (17)}

http://dx.doi.org/10.1016/j.carres.2013.12.026 
Diisopropyl azodicarboxylate $(1.33 \mathrm{~mL}, 6.8 \mathrm{mmol})$ was added to a solution of 15 (2.0 $\mathrm{g}, 5.73 \mathrm{mmol})$ and $\mathrm{PPh}_{3}(1.79 \mathrm{~g}, 6.87 \mathrm{mmol})$ in $\mathrm{THF}(50 \mathrm{~mL})$ at $0{ }^{\circ} \mathrm{C}$ and the mixture was stirred for $20 \mathrm{~min}$ at $0{ }^{\circ} \mathrm{C}$. Then diphenylphosphoryl azide $(1.48 \mathrm{~mL}, 6.86 \mathrm{mmol})$ in THF (12 $\mathrm{mL}$ ) was added and the mixture was stirred for $24 \mathrm{~h}$ at $\mathrm{rt}$. Then the mixture was concentrated, the residue was taken up in EtOAc $(300 \mathrm{~mL})$ and washed with sat. $\mathrm{NaHCO}_{3}$ solution $(150$ $\mathrm{mL}$ ), the organic layer was dried, filtered and concentrated. Column chromatography $\left(\mathrm{CH}_{2} \mathrm{Cl}_{2}-\mathrm{EtOAc} ; 95: 5\right)$ of the residue followed by recrystallization from hexane/EtOAc afforded $17(1.27 \mathrm{~g}, 60 \%)$ as white crystals: $\mathrm{mp} 161-163{ }^{\circ} \mathrm{C} ;[\alpha]_{D}^{25} 17.8\left(c 0.89, \mathrm{CHCl}_{3}\right) ;{ }^{1} \mathrm{H}$ NMR: $\delta 7.55$ - 7.33 (m, 5 H, aromatic), 5.60 (s, 1 H, -CHPh), 4.70 (s, 1 H, H-1), 4.32 (dd, 1 H, $J_{\text {gem }} 9.9$ Hz, H-6a), 4.20 (m, 1 H, H-5), 4.13 (m, 1 H, H-3), 4.01 (dd, 1 H, $J_{3,4} 3.8$ Hz, $J_{4,5}$ $9.8 \mathrm{~Hz}, \mathrm{H}-4), 3.74$ (dd, 1 H, H-6b), 3.38 (s, 3 H, OMe), 2.86 (d, 1 H, J2,3 1.2 Hz, H-2), 2.72 and 2.55 (each m, each $2 \mathrm{H}, 2-\mathrm{CH}_{2^{-}}$), 1.60 and 1.45 (m, $\left.6 \mathrm{H},-\mathrm{CH}_{2^{-}}\right) ;{ }^{13} \mathrm{C}$ NMR: $\delta$ 137.1, 129.1, 128.3 and 126.1 (aromatic), 102.2 (-CHPh), 101.3 (C-1), 77.7 (C-4), 69.4 (C-6), 67.4 (C-2), 58.0 (C-5), 56.0 (C-3), $55.2(\mathrm{OMe}), 51.7,26.5$ and $24.2\left(5-\mathrm{CH}_{2}\right)$; MS: Calcd. for: $\mathrm{C}_{19} \mathrm{H}_{26} \mathrm{~N}_{4} \mathrm{O}_{4} 374$, found: $375[\mathrm{M}+\mathrm{H}]^{+}$. Anal. Calcd for $\mathrm{C}_{19} \mathrm{H}_{26} \mathrm{~N}_{4} \mathrm{O}_{4}$ : C, 60.95; H, 7.00. Found: C, 60.99; H, 7.01.

\subsection{Methyl 3-azido-4,6- $O$-benzylidene-2,3-dideoxy-2-morpholino- $\alpha$-D- mannopyranoside (18)}

Compound 16 ( $2.0 \mathrm{~g}, 5.73 \mathrm{mmol})$ was converted into the azido derivative as described for 17. Column chromatography $\left(\mathrm{CH}_{2} \mathrm{Cl}_{2}-\mathrm{EtOAc}, 95: 5\right)$ followed by crystallization from hexane/EtOAc afforded $18(1.49 \mathrm{~g}, 69 \%)$ as white crystals: mp 164-166 ${ }^{\circ} \mathrm{C} ;[\alpha]_{D}^{25} 26.2(c$ 0.62, $\left.\mathrm{CHCl}_{3}\right) ;{ }^{1} \mathrm{H}$ NMR: $\delta 7.54$ - 7.34 (m, $5 \mathrm{H}$, aromatic), 5.61 (s, $\left.1 \mathrm{H},-\mathrm{CHPh}\right), 4.72(\mathrm{~s}, 1 \mathrm{H}$, H-1), 4.30 (dd, 1 H, J Jem 10.0 Hz, H-6a), 4.21 (m, 1 H, H-5), 4.11 (m, 1 H, H-3), 4.04 (dd, 1 H, $\left.J_{3,4} 3.6 \mathrm{~Hz}, J_{4,5} 9.2 \mathrm{~Hz}, \mathrm{H}-4\right), 3.73$ (dd, $\left.1 \mathrm{H}, \mathrm{H}-6 \mathrm{~b}\right), 3.70$ (t, $4 \mathrm{H},-\mathrm{CH}_{2} \mathrm{OCH}_{2^{-}}$), 3.38 (s, $3 \mathrm{H}$, OMe), 2.81 (d, $1 \mathrm{H}, J_{2,3} 1.3 \mathrm{~Hz}, \mathrm{H}-2$ ), 2.75 and 2.64 (each m, each $2 \mathrm{H}, 2-\mathrm{CH}_{2^{-}}$); ${ }^{13} \mathrm{C}$ NMR: $\delta$ 137.0, 129.2, 128.3 and 126.1 (aromatic), 102.3 (-CHPh), 100.0 (C-1), 77.4 (C-4), 69.2 (C-6), $67.3\left(-\mathrm{CH}_{2} \mathrm{OCH}_{2}-\right), 66.5(\mathrm{C}-2), 58.1(\mathrm{C}-5), 56.5(\mathrm{C}-3), 55.4(\mathrm{OMe}), 50.9\left(2-\mathrm{CH}_{2}\right)$; MS: Calcd. for: $\mathrm{C}_{18} \mathrm{H}_{24} \mathrm{~N}_{4} \mathrm{O}_{5} 376$, found: $377[\mathrm{M}+\mathrm{H}]^{+}$. Anal. Calcd for $\mathrm{C}_{18} \mathrm{H}_{24} \mathrm{~N}_{4} \mathrm{O}_{5}: \mathrm{C}, 57.44 ; \mathrm{H}, 6.43$. Found: C, 57.57; H, 6.44. 


\subsection{Methyl 4,6- $O$-benzylidene-2,3-dideoxy-2-piperidino-3-( $N$ '-phenyl)thioureido- $\alpha$-D- mannopyranoside (19)}

Triphenylphosphine $(1.51 \mathrm{~g}, 5.7 \mathrm{mmol})$ was added to a solution of $\mathbf{1 7}(1.2 \mathrm{~g}, 3.2$ $\mathrm{mmol})$ in THF $(15 \mathrm{~mL})$ at $\mathrm{rt}$ and the mixture was stirred for $2 \mathrm{~h}$ at $80^{\circ} \mathrm{C}$. When TLC (hexane:EtOAc; $1: 1)$ showed the absence of the starting material water $(0.75 \mathrm{~mL})$ was added to the mixture and the stirring was continued for $4 \mathrm{~h}$ at $80^{\circ} \mathrm{C}$. Evaporation of the solvent and column chromatography $\left(\mathrm{CH}_{2} \mathrm{Cl}_{2}-\mathrm{MeOH} ; 98: 2\right)$ of the residue afforded the 3-amino derivative $(900 \mathrm{mg})$. Phenyl isothiocyanate $(300 \mu \mathrm{L})$ was added to a solution of the amino derivative $(600 \mathrm{mg})$ in $\mathrm{MeOH}(10 \mathrm{~mL})$ at rt. The mixture was stirred for $30 \mathrm{~min}$ then concentrated and the product was isolated by column chromatography $\left(\mathrm{CH}_{2} \mathrm{Cl}_{2}-\mathrm{MeOH} ; 98: 2\right)$. Compound 19 (733 mg, 71\%) was obtained as a syrup: $[\alpha]_{D}^{25} 18.7\left(c 0.82, \mathrm{CHCl}_{3}\right) ;{ }^{1} \mathrm{H} \mathrm{NMR}$ : $\delta 8.2$ (bs, $1 \mathrm{H}, \mathrm{NH}), 7.80$ - 7.00 (m, $10 \mathrm{H}$, aromatic), 5.65 (s, $1 \mathrm{H},-\mathrm{CHPh}), 4.76$ (s, $1 \mathrm{H}, \mathrm{H}-1)$, 4.20 (m, 2 H, H-4 and H-6a), 3.79 (dd, 1 H, H-6b), 3.65 (bs, 1 H, H-5), 3.33 (bs, 3 H, OMe), $2.80-2.50\left(\mathrm{~m}, 4 \mathrm{H}, \mathrm{H}-2, \mathrm{H}-3\right.$ and $\left.2-\mathrm{CH}_{2^{-}}\right), 1.58$ and $1.45\left(\mathrm{~m}, 6 \mathrm{H},-\mathrm{CH}_{2^{-}}\right) ;{ }^{13} \mathrm{C} \mathrm{NMR}: \delta 181.0$ $(\mathrm{C}=\mathrm{S}), 137.6,137.1,131.9,131.8,131.7,128.4$, and 126.0 (aromatic), 101.6 (-CHPh), 99.4 (C-1), 76.0 (C-4), 69.2 (C-6), 66.2 (C-2), 59.4 (C-5), $55.6(\mathrm{OMe}), 52.0\left(2-\mathrm{CH}_{2}\right), 51.8$ (C-3), 26.3 and 24.1 (3- $\left.\mathrm{CH}_{2}\right)$; MS: Calcd. for: $\mathrm{C}_{26} \mathrm{H}_{33} \mathrm{~N}_{3} \mathrm{O}_{4} \mathrm{~S} 483$, found: 484 [M+H] $]^{+}$. Anal. Calcd for $\mathrm{C}_{26} \mathrm{H}_{33} \mathrm{~N}_{3} \mathrm{O}_{4} \mathrm{~S}: \mathrm{C}, 64.57 ; \mathrm{H}, 6.88$. Found: C, 64.37; H, 6.91.

\subsection{Methyl 4,6-O-benzylidene-2,3-dideoxy-2-piperidino-3-( $N$ '-3,5- bis(trifluoromethyl)phenyl)thioureido- $\alpha$-D-mannopyranoside (20)}

Compound 17 was converted into the 3-amino derivative as described for compound 19. 3,5-Bis(trifluoromethyl)phenyl isothiocyanate $(470 \mu \mathrm{L})$ was added to a solution of the 3amino derivative $(600 \mathrm{mg})$ in $\mathrm{MeOH}(10 \mathrm{~mL})$ at $\mathrm{rt}$. The mixture was stirred for $30 \mathrm{~min}$ then concentrated. Column chromatography $\left(\mathrm{CH}_{2} \mathrm{Cl}_{2}-\mathrm{EtOAc} ; 98: 2\right)$ of the residue provided 20 (900 mg, 81\%) as a syrup: $[\alpha]_{D}^{25}-41.7\left(c\right.$ 0.69, $\left.\mathrm{CHCl}_{3}\right)$; ${ }^{1} \mathrm{H}$ NMR: $\delta 8.76$ (bs, $\left.1 \mathrm{H}, \mathrm{NH}\right), 7.70$ 7.30 (m, 8 H, aromatic), 5.70 (s, 1 H, -CHPh), 4.86 (s, $1 \mathrm{H}, \mathrm{H}-1), 4.30$ (m, $2 \mathrm{H}, \mathrm{H}-4$ and H6a), 4.10 (m, 1 H, H-5), 3.82 (dd, 1 H, H-6b), 3.40 (bs, 3 H, OMe), 2.80 - 2.55 (m, 4 H, H-2, $\mathrm{H}-3$ and $2-\mathrm{CH}_{2^{-}}$), 1.58 and 1.45 (m, $\left.6 \mathrm{H},-\mathrm{CH}_{2^{-}}\right) ;{ }^{13} \mathrm{C}$ NMR: $\delta 183.2(\mathrm{C}=\mathrm{S}), 136.5$ (aromatic), 131.0 (C-3" and C-5"), 128.5, 128.3 and 128.1 (aromatic), 122.8 (q, 2 C, ${ }^{1} J_{\mathrm{C}, \mathrm{F}} 271 \mathrm{~Hz}, 2 \mathrm{CF}_{3}$ ), 123.1 (m, 2 C, C-2” and C-6”), 102.8 (-CHPh), 99.3 (C-1), 77.5 (C-4), 69.1 (C-6), 66.4 (C-2), 
Carbohydrate Research 389 (2014) 50-56

59.8 (C-5), $55.5(\mathrm{OMe}), 53.1(\mathrm{C}-3), 52.0\left(2-\mathrm{CH}_{2}\right), 26.4$ and $24.1\left(3-\mathrm{CH}_{2}\right)$; MS: Calcd. for: $\mathrm{C}_{28} \mathrm{H}_{31} \mathrm{~F}_{6} \mathrm{~N}_{3} \mathrm{O}_{4} \mathrm{~S} 619$, found: $620[\mathrm{M}+\mathrm{H}]^{+}$. Anal. Calcd for $\mathrm{C}_{28} \mathrm{H}_{31} \mathrm{~F}_{6} \mathrm{~N}_{3} \mathrm{O}_{4} \mathrm{~S}: \mathrm{C}, 54.28 ; \mathrm{H}, 5.04$. Found: C, 54.16; H, 5.04.

\subsection{Methyl 4,6-O-benzylidene-2,3-dideoxy-2-morpholino-3-( $N$ '-phenyl)thioureido- $\alpha$ - D-mannopyranoside (21)}

Compound 18 (2.46 g, $6.5 \mathrm{mmol})$ was converted into the 3-amino derivative (1.34 g) as described for 19. Phenyl isothiocyanate $(130 \mu \mathrm{L})$ was added to a solution of the crude amino derivative $(251 \mathrm{mg})$ in $\mathrm{MeOH}(8 \mathrm{~mL})$ at $\mathrm{rt}$. The mixture was stirred for $30 \mathrm{~min}$, the product, which formed as a precipitate, was filtered and was recrystallized from EtOAc/hexane to afford 21 (167 mg, 29\% over two steps) as white crystals: mp 192-193 ${ }^{\circ} \mathrm{C}$; $[\alpha]_{D}^{25} 45.9\left(c 0.84, \mathrm{CHCl}_{3}\right)$; ${ }^{1} \mathrm{H} \mathrm{NMR}: \delta 8.40$ (bs, $\left.1 \mathrm{H}, \mathrm{NH}\right), 7.50-7.20$ (m, $10 \mathrm{H}$, aromatic), 5.65 (s, 1 H, -CHPh), 4.67 (s, 1 H, H-1), 4.20 (m, 2 H, H-4 and H-6a), 3.78 (t, 1 H, H-6b), 3.70 (t, $4 \mathrm{H},-\mathrm{CH}_{2} \mathrm{OCH}_{2}$ ) , 3.60 (bs, $\left.1 \mathrm{H}, \mathrm{H}-5\right), 3.10$ (s, $\left.3 \mathrm{H}, \mathrm{OMe}\right), 2.80$ and 2.60 (m, $6 \mathrm{H}, \mathrm{H}-$ 2, H-3 and $\left.2-\mathrm{CH}_{2}-\right) ;{ }^{13} \mathrm{C}$ NMR: $\delta 180.6(\mathrm{C}=\mathrm{S}), 137.0,129.4,128.7,128.0,125.9$, and 125.1 (aromatic), 101.6 (-CHPh), 98.2 (C-1), 75.2 (C-4), 69.0 (C-6), $67.2\left(-\mathrm{CH}_{2} \mathrm{OCH}_{2}-\right), 65.4$ (C-2), 59.5 (C-5), 55.7 (OMe), $51.4(\mathrm{C}-3), 51.2\left(2-\mathrm{CH}_{2}\right)$; MS: Calcd. for: $\mathrm{C}_{25} \mathrm{H}_{31} \mathrm{~N}_{3} \mathrm{O}_{5} \mathrm{~S} 485$, found: $486[\mathrm{M}+\mathrm{H}]^{+}, 508[\mathrm{M}+\mathrm{Na}]^{+}$. Anal. Calcd for $\mathrm{C}_{25} \mathrm{H}_{31} \mathrm{~N}_{3} \mathrm{O}_{5} \mathrm{~S}: \mathrm{C}, 61.83 ; \mathrm{H}, 6.43$. Found: $\mathrm{C}$, $61.87 ; \mathrm{H}, 6.54$.

\subsection{Methyl 4,6-O-benzylidene-2,3-dideoxy-2-morpholino-3-( $N$ '-3,5- bis(trifluoromethyl)phenyl)thioureido- $\alpha$-D-mannopyranoside (22)}

Compound 18 (2.46 g, $6.5 \mathrm{mmol})$ was converted into the 3-amino derivative (1.34 g) as described for 19. 3,5-Bis(trifluoromethyl)phenyl isothiocyanate $(720 \mu \mathrm{L})$ was added to a solution of the crude amino derivative $(920 \mathrm{mg})$ in $\mathrm{MeOH}(10 \mathrm{~mL})$ at $\mathrm{rt}$. The mixture was stirred for $30 \mathrm{~min}$ then concentrated. Column chromatography $\left(\mathrm{CH}_{2} \mathrm{Cl}_{2}-\mathrm{EtOAc} ; 98: 2 \rightarrow 95: 5\right)$ of the residue afforded $22(733 \mathrm{mg}, 27 \%)$ as a syrup: $[\alpha]_{D}^{25}-23.4\left(c 0.74, \mathrm{CHCl}_{3}\right) ;{ }^{1} \mathrm{H}$ NMR: $\delta 8.70$ (bs, $1 \mathrm{H}, \mathrm{NH}), 7.50-7.10$ (m, $8 \mathrm{H}$, aromatic), 5.70 (s, $1 \mathrm{H},-\mathrm{CHPh}), 4.78$ (s, $1 \mathrm{H}, \mathrm{H}-1)$, 4.35 (m, 2 H, H-4 and H-6a), 3.81 (dd, 1 H, H-6b), 3.70 (m, 5 H, H-5 and $2 \times-\mathrm{CH}_{2}-$ ), 3.40 (bs, $3 \mathrm{H}, \mathrm{OMe}$ ), $2.80-2.60$ (m, $6 \mathrm{H}, \mathrm{H}-2, \mathrm{H}-3$ and $2-\mathrm{CH}_{2^{-}}$); ${ }^{13} \mathrm{C}$ NMR: $\delta 183.1(\mathrm{C}=\mathrm{S}), 136.2$ (aromatic), 130.2 (C-3" and C-5”), 128.9, 128.6 and 128.3 (aromatic), 122.8 (q, 2 C, ${ }^{1} J_{\mathrm{C}, \mathrm{F}} 270$ 
Hz, $2 \mathrm{CF}_{3}$ ), 123.1 (m, 2 C, C-2” and C-6”), 102.8 (-CHPh), 98.5 (C-1), 77.4 (C-4), 69.0 (C-6), $67.2\left(-\mathrm{CH}_{2} \mathrm{OCH}_{2}-\right), 65.8(\mathrm{C}-2), 59.1(\mathrm{C}-5), 55.6(\mathrm{OMe}), 52.8(\mathrm{C}-3), 51.2\left(2-\mathrm{CH}_{2}\right)$; MS: Calcd. for: $\mathrm{C}_{27} \mathrm{H}_{29} \mathrm{~F}_{6} \mathrm{~N}_{3} \mathrm{O}_{5} \mathrm{~S} 621$, found: $622[\mathrm{M}+\mathrm{H}]^{+}$; HRMS: [M+Na] $]^{+}$calcd. for 644.1624, found: 644.1629.

\subsection{General procedure for the Michael addition}

Organocatalyst $(0.02 \mathrm{mmol})$ was added to a solution of $\beta$-nitrostyrene $(0.2 \mathrm{mmol})$ in $\mathrm{CH}_{2} \mathrm{Cl}_{2}(0.5 \mathrm{~mL})$ under Ar at rt. The mixture was stirred for $5 \mathrm{~min}$, then acetylacetone $(0.22$ mmol) was added and stirring was continued for $24 \mathrm{~h}$ at $\mathrm{rt}$. The mixture was concentrated and the product was isolated by column chromatography (Hexane-EtOAc; 7:3). The ratio of the formed enantiomers was determined by chiral HPLC method: $t_{\text {major }}: 9.3 \min t_{\text {minor }}: 12.5$ min.

\subsection{3. (S)-3-(2-Nitro-1-phenylethyl)-pentane-2,4-dione (23)}

${ }^{1} \mathrm{H}$ NMR: $\delta$ 7.35-7.15 (m, $5 \mathrm{H}$, aromatic), 4.62-4.58 (m, $\left.2 \mathrm{H}\right), 4.36$ (d, J=10.8 Hz, $\left.1 \mathrm{H}\right), 4.28$ 4.20 (m, $1 \mathrm{H}), 2.30$ (s, $3 \mathrm{H}), 1.95$ (s, $3 \mathrm{H}) ;{ }^{13} \mathrm{C}$ NMR: $\delta 201.7,201.0,136.0,129.3,128.5$, 128.0, 78.1, 70.7, 42.8, 30.4, 29.5.

\section{Acknowledgements}

The authors thank Mrs. Roczkov Ivánné for performing combustion analysis, Dr. Palkó Roberta for helpful support with chiral HPLC measurements, Dr. Szilárd Varga for supporting us with $\beta$-nitrostyrene and for Dr. Tibor Soós for fruitful discussions.

\section{Supplementary data}

Supplementary data associated with this article can be found, in the online version, at...

\section{References}

1. (a) Dalko, P. I.; Moisan, L. Angew. Chem. Int. Ed. 2004, 43, 5138-5175; (b) Taylor, M. S.; Jacobsen, E. N. Angew. Chem. Int. Ed. 2006, 45, 1520-1543.

2. Okino, T., Hoashi, Y.; Takemoto, Y. J. Am. Chem. Soc. 2003, 125, 12672-12673.

3. Wang, J.; Li, H., Duan, W.; Zu, L.; Wang, W. Org. Lett. 2005, 7, 4713-4716. 
4. Vakulya, B.; Varga, Sz.; Csámpai, A., Soós, T. Org. Lett. 2005, 7, 1967-1969.

5. Becker, C.; Hoben, C.; Kunz, H. Adv. Synth. Catal. 2007, 349, 417-424.

6. (a) Liu, K.; Cui, H.-F.; Nie, J.; Dong, K.-Y.; Li, X.-J.; Ma, J.-A. Org. Lett. 2007, 9, 923 925; (b) Wang, C.; Zhou, Z.; Tang, C. Org. Lett. 2008, 10, 1707-1710; (c) Gao, P.; Wang, C.;

Wu, Y.; Zhou, Z.; Tang, C. Eur. J. Org. Chem. 2008, 4563-4566; (d) Lu, A.; Gao, P.; Wu. Y.; Wang, Y.; Zhou, Z.; Tang, C. Org. Biomol. Chem. 2009, 7, 3141-3147; (e) Ma, H.; Liu, K.; Zhang, F.-G.; Zhu, C.-L.; Nie, J.; Ma, J.-A. J. Org. Chem. 2010, 75, 1402-1409.

7. Puglisi, A.; Benaglia, M.; Raimondi, L.; Lay, L.; Poletti, L. Org. Biomol. Chem. 2011, 9, 3295-3302.

8. Fuller, T. S.; Stick, R. V. Aust. J. Chem. 1980, 30, 2509-2515.

9. The use of propanedithiol for the reduction of carbohydrate derived azides was first described in: Oertel, K.; Zech, G.; Kunz, H. Angew. Chem. Int. Ed. 2000, 39, 1431-1433. 10. Robertson, G. J.; Griffith, C. F. J. Chem. Soc., 1935, 1193-1201.

11. Vega-Perez, J. M.; Candela, J. I.; Vega, M.; Iglesias-Guerra, F. Carbohydr. Res. 1995, 279, C5-C8.

12. Thompson, A. S.; Humphrey, G. R.; DeMarco, A. M.; Mathre, D. J.; Grabowsky, E. J. J. Org. Chem. 1993, 58, 5886-5888.

13. (a) Wang, J.; Li, H.; Duan, W.; Zu, L.; Wang, W. Org. Lett. 2005, 7, 4713 - 4716; (b) Okino, T.; Hoashi, Y.; Furukawa, T.; Xu, X.; Takemoto, Y. J. Am. Chem. Soc. 2005, 127, 119-125; (c) Andres, J. M.; Manzano, R.; Pedrosa, R. Chem. Eur. J. 2008, 14, 5116-5119; (d) Li, H.; Zhang, X.; Shi, X.; Ji, N.; He, W.; Zhang, S.; Zhang, B. Adv. Synt. Catal. 2012, 354, 2264-2274; (e) Kasaplar, P.; Riente, P.; Hartmann, C.; Pericas, M. A.; Pericas, M. A. Adv. Synt. Catal. 2012, 354, 2905-2910. 